\title{
Ações eleitorais. Atualidades sobre conexão, continência, litispendência e coisa julgada
}

\author{
luizfernando.pereira@vgpadvogados.com.br \\ Vernalha Guimarães \& pereira Adv. Associados. \\ Rua Mateus Leme - 575 São Francisco 80510192 \\ Curitiba, PR - Brasil
}

Luiz Fernando Casagrande Pereira ${ }^{1}$ (UFPR. Brasil)

\footnotetext{
1. Doutor e Mestre em Direito pela UFPR. Professor de Direito Processual Civil e Direito Eleitoral em diversas instituições. Coordenador da pós-graduação em Direito Eleitoral da Universidade Positivo. É palestrante e autor de inúmeros livros e artigos na área de Direito Processual Civil e Direito Eleitoral.
} 


\title{
Resumo
}

O texto aborda o impacto da última reforma eleitoral, Lei n $13.165 / 2015$, nas açóes eleitorais típicas para cassação de mandato, especialmente em relação aos institutos da conexão, continência, litispendência e coisa julgada. Estes institutos de processo foram mal tratados pela jurisprudência eleitoral durante muito tempo. Com a introdução do art. 96-B na Lei Eleitoral (introduzido pela Lei 13.165/2015), a matéria ganha uma disciplina mais consentânea com a melhor orientação (em doutrina e jurisprudência).

O artigo também demonstra que, intencionalmente ou não, a reforma (como já sustentava parcela da doutrina) também aproximou a tutela jurisdicional eleitoral do microssistema dos processos coletivos, com importantes repercussões. Além disso, em breve haverá a vigência do Novo Código de Processo Civil. Tudo isso póe em destaque a importância de aferir o espaço de aplicação subsidiária (ora do NCPC; ora dos processos coletivos) para definir a correta interpretação do novo art. 96-B da Lei Eleitoral.

\section{Palavras-chave: Reforma Eleitoral; Cassação de Mandato; Ação Eleitoral}

\begin{abstract}
The article examines the impact of the most recent reform of the electoral rules, by means of Law 13,165/2015, regarding the typical electoral lawsuits to remove elected officials from office, especially with respect to the mechanisms of joinder, lis pendens and res judicata. These procedural instruments were poorly dealt with by the electoral jurisprudence for a long time. With the introduction of Article 96-B in the Electoral Law (introduced by Law $13,165 / 2015$ ), these matters have gained more solid footing, with better interpretation (in doctrine and jurisprudence.

The article also demonstrates that, intentionally or not, the reform (as already argued by a current in the doctrine) also has brought the judicial activity regarding politics closer to the micro-system of the collective actions, with important repercussions. Besides this, the new Civil Procedure Code will take effect soon. All this highlights the importance of opening space for subsidiary application (both in the new $\mathrm{CPC}$ and regarding collective actions) to define the correct interpretation of the new Article 96-B of the Electoral Law.
\end{abstract}

Keywords: Electoral Reform; Removal from Office; Electoral Lawsuit 


\section{Introdução}

De forma nitidamente açodada, o Congresso promoveu uma (mais uma) reforma na legislação eleitoral. É a Lei 13.165/2015, com impactos importantes - muitos negativos - no ambiente do contencioso eleitoral. Aqui a ideia é abordar o impacto da reforma no ambiente das ações eleitorais típicas para cassação de mandato, especialmente em relação aos institutos da conexão, continência, litispendência e coisa julgada. Estes institutos de processo foram mal tratados pela jurisprudência eleitoral durante muito tempo. Com a introdução do art. 96-B na Lei Eleitoral (introduzido pela Lei 13.165/2015), a matéria ganha uma disciplina mais consentânea com a melhor orientação (em doutrina e jurisprudência).

Intencionalmente ou não, a reforma (como já sustentava parcela da doutrina) também aproximou a tutela jurisdicional eleitoral do microssistema dos processos coletivos, com importantes repercussões. Além disso, em breve haverá a vigência do Novo Código de Processo Civil. Tudo isso põe em destaque a importância de aferir o espaço de aplicação subsidiária (ora do NCPC; ora dos processos coletivos) para definir a correta interpretação do novo art. 96-B da Lei Eleitoral. É a ideia deste texto.

\section{As ações eleitorais típicas para cassação de mandato. Avanços e retrocessos}

Há reconhecida balbúrdia legislativa no direito processual eleitoral. ${ }^{2}$ A carência de homogeneidade se dá em razão de a disciplina de processo do Direito Eleitoral estar distribuída em leis esparsas, concebidas em tempos diferentes, sem o compromisso com um sistema organizado. E é possível dizer que já foi pior. Alguns avanços importantes deram mais racionalidade às técnicas processuais do contencioso eleitoral, especialmente em relação às demandas que têm por objeto a cassação de mandato.

O maior problema - que persiste em alguma medida - é a sobreposição de ações eleitorais típicas com o mesmo objetivo. Aquilo que Rodolfo VIANA PEREIRA foi feliz em batizar de bizarra existência simultânea de mecanismos de impugnação pós-eleitoral. ${ }^{3} \mathrm{~A}$ ação de investigação judicial eleitoral (AIJE), art. 22 da Lei 64/90; a ação de impugnação de mandato eletivo (AIME), art. 14, $\S 10^{\circ}$, da Constituição Federal; o recurso contra expedição de diploma (RCDE), art. 262 do Código Eleitoral; as representações eleitorais da Lei 9.504/97. ${ }^{4}$

\section{RODRIGUES, Marcelo Abelha; CHEIM JORGE, Flavio. Manual de Direito Eleitoral. São Paulo: RT, 2014, p. 275.}

3. Tutela Coletiva no Direito Eleitoral: Controle Social e Fiscalização das Eleiçóes. Lumen Juris, 2008, p. 106.

4. O Ministro Dias Toffoli, no RCED no 884, reconheceu o problema“(...) há que se considerar as dificuldades decorrentes da admissibilidade de mais de uma ação eleitoral fundamentada em idênticos fatos e com o mesmo objetivo, qual seja, a desconstituição do diploma. Essa circunstância, além de proporcionar um número crescente de açôes nesta Justiça Especializada, comprometendo a eficiência da prestação jurisdicional, traz o risco imanente de decisóes conflitantes (...)". No mesmo sentido o Ministro Henrique Neves: "Realmente, para a Justiça Eleitoral não é interessante a existência de múltiplos processos, cada um julgado num momento" (REspe no 1-67, Rel. Min. Luciana Lóssio, red. p/ acórdão Min. Henrique Neves, DJe 29/09/2014). 
Todas estas ações poderiam conduzir à cassação, com um espaço coincidente (zona de intersecção) nas causas de pedir abstratamente consideradas. ${ }^{5}$

Algumas alterações legislativas melhoraram a organicidade. A começar pela supressão do inciso XV da Lei 64/90, em mudança patrocinada pela Lei Complementar 135/2010. ${ }^{6}$ Até então a AIJE tinha a aptidão de produzir a cassação do mandato apenas se fosse julgada até a eleição (ou diplomação, em alguns julgados). ${ }^{7}$ Se o julgamento ocorresse depois da eleição/ diplomação - o que era regra -, a desconstituição do diploma ou do mandato só era possível com a propositura de uma nova ação (RCED ou AIME). A AIJE, quase sempre, funcionava como um mero procedimento prévio de instrução de futura AIME ou RCED. ${ }^{8}$

A função meramente instrumental da AIJE tinha relação com a original ausência de caráter jurisdicional da medida, tal como estava na redação inicial do art. $237, \S 2^{\circ}$, do Código Eleitoral. Tratava-se de mero procedimento administrativo para investigar. Foi a LC 64/90 que entregou natureza de ação (jurisdicional) para a AIJE. ${ }^{9}$ A entrega de natureza jurisdicional, entretanto, não veio acompanhada de autonomia funcional.

Foi, enfim, a supressão do art. XV da Lei 64/90 que ofereceu autonomia funcional para a AIJE - passando a ter uma sentença efetiva para cassações independente do momento do julgamento de mérito. Por outro lado, a ampliação da eficiência processual da AIJE agravou o problema da sobreposição de ações com o mesmo objetivo: AIJE, AIME, Representações e RCDE - que não é recurso, mas ação desconstitutiva de diploma.

Com a Lei $\mathrm{n}^{\circ} 12.891 / 2013$, art. 262 foi amputado e o RCED teve seu escopo reduzido apenas para inelegibilidade superveniente ou de natureza constitucional e de falta de condição de elegibilidade. A alteração legislativa foi precedida de decisão do TSE, em controle de constitucionalidade, com idêntica consequência. ${ }^{10}$ Reconheceu-se a não recepção do RCED para tratar de causas de pedir que tinham sido alocadas, pela Constituição de 88, no escopo da AIME. ${ }^{11}$ Os abusos ficaram apenas para ser veiculados em AIJE ou AIME (ou Representa-

5. Muitas vezes, a expressão “cassação", no presente artigo, será utilizada para designar, indistintamente, cassação de registro, de diploma ou do próprio mandato. Também equivalente à cassação se considerada a inelegibilidade cominada simples para a eleição, na classificação de Adriano Soares da COSTA. Cassação como pedido mediato, enfim. Didaticamente, para o objetivo do estudo, quase sempre a distinção não tem especial relevância. Em necessidade de se distinguir, o artigo póe em destaque as diferenças.

6. Era assim a redação do dispositivo revogado: "Art. 22, (...) XV - se a representação for julgada procedente após a eleição do candidato serão remetidas cópias de todo o processo ao Ministério Público Eleitoral, para os fins previstos no art. 14, $\$ \$ 10$ e 11 da Constituição Federal, e art. 262, inciso IV, do Código Eleitoral".

7."A cassação de registro de candidatura, em sede de investigação judicial, somente é possível caso seja esse feito julgado antes das eleições, conforme interpretação do art. 22, XIV e XV, da Lei Complementar nº 64/90" (RESP n 25673, Rel. Min. Caputo Bastos, 05/05/2006).

8. Sobre o tema, antes da mudança, conferir: SILVA, Luis Gustavo Motta Severo da. A inefetividade da Ação de Investigação Judicial Eleitoral. In: GONÇALVES, Guilherme de Salles; PEREIRA, Luiz Fernando Casagrande (Orgs.). Direito Eleitoral Contemporâneo, Belo Horizonteः Fórum, 2008.

9. CASTRO, Edson Resende. Curso de Direito Eleitoral, Ed. Del Rey, 7. ed. p. 351.

10. O TSE já tinha decidido ser "incabivel o recurso contra expedição de diploma com fundamento no art. 262, IV, do Código Eleitoral, uma vez que tal dispositivo não foi recepcionado pela Constituição Federal” (AgRRCED 305-92, rel. Min. Laurita Vaz, 20.6.2014).

11. RCED 8-84/PI, Rel. Min. Dias Toffoli, 17.9.2013. 
ções nos abusos típicos). A verdade é que as reformas patrocinaram um enxugamento das ações eleitorais típicas.

Bem analisada a questão, sequer haveria a necessidade de ações típicas para veicular pretensão de cassações de mandatos. ${ }^{12}$ Todas as causas de pedir possíveis poderiam ser deduzidas em uma ação eleitoral atípica, de cognição exauriente. Importante notar que não há procedimentos especiais. Todas as hipóteses que podem conduzir à cassação (inclusive as Representações da Lei Eleitoral) seguem o rito do art. $22 \mathrm{da} \mathrm{LC} 64 / 90 .{ }^{13}$ Os procedimentos especiais só se justificariam se houvesse um ganho de eficiência. ${ }^{14} \mathrm{~A}$ ausência de particularidades relevantes no âmbito do direito material e a celeridade própria do direito eleitoral dispensam os procedimentos especiais.

De qualquer forma, a verdade é que, apesar das reformas, ainda há espaço para a sobreposição entre Representações, AIJE e AIME na zona de interseç̧ão das causas de pedir comuns, abstratamente consideradas (abuso do poder econômico e político). ${ }^{15}$ Não obstante, o TSE (e toda a jurisprudência eleitoral) se recusava a reconhecer a possibilidade de litispendência, coisa julgada ou conexão nestas ações sobrepostas - gerando perplexidade processual. ${ }^{16}$

É claro que o espaço de incidência desta perplexidade processual diminuiu muito desde a vigência das mudanças comentadas, mas ainda restou um ambiente remanescente nos casos de tramitação simultânea e sobreposta de AIJE, AIME e, em alguns casos, Representaçóes da Lei Eleitoral.17 Ou das mesmas ações eleitorais típicas com objeto comum, mas autores distintos, incluindo as ações de impugnação de registro de candidatura. A Lei no 13.165/2015 teve a pretensão de estabelecer um convivio processualmente harmônico entre estas demandas, com a adoção de técnicas próprias do microssistema do processo coletivo. É imperioso compreender muito bem esta mudança de paradigma, especialmente pela vigência imediata (art. 14 da Lei) e aplicação aos processos em curso. ${ }^{18}$

12. DINAMARCO, Cândido Rangel. Das ações típicas..., p. 484-485.

13. Na Res. 21.634, o TSE definiu que, diante da ausência de previsão, aplicava-se o procedimento do art. 30 à AIME, visto que este seria o "ordinário eleitoral".

14. SICA, Heitor Vitor Mendonça. Reflexões em torno da Teoria Geral dos procedimentos especiais. In: Revista de Processo, v. 208, ano 37. São Paulo: Editora RT, jun. 2012.

15. "O abuso de poder econômico entrelaçado com o abuso de poder político pode ser objeto de Ação de Impugnação de Mandato Eletivo (AIME), porquanto abusa do poder econômico o candidato que despende recursos patrimoniais, públicos ou privados, dos quais detém o controle ou a gestão em contexto revelador de desbordamento ou excesso no emprego desses recursos em seu favorecimento eleitoral" (AgR-AI n 11.708/MG, rel. Min. Félix Fischer, DJE de 15.4.2010). A expressão “zona de intersecção" é de Felipe Lopes SOARES, ao tratar da "Litispendência entre ação civil pública e ação popular". In: Revista de Processo. v. 171, ano 34. São Paulo: Editora RT, mai. 2009, p. 151.

16. "O recurso contra expedição de diploma (RCED) é instrumento processual adequado à proteção do interesse público na lisura do pleito, assim como o são a ação de investigação judicial eleitoral (AIJE) e a ação de impugnação de mandato eletivo (AIME). Todavia, cada uma dessas açóes constitui processo autônomo, dado possuírem causas de pedir próprias e consequências distintas, o que impede que o julgamento favorável ou desfavorável de alguma delas tenha influência no trâmite das outras" (ED em RCED nº69, Relator(a) Min. Félix Fischer, Data 05/10/2009).

17. "O anterior ajuizamento de ações de investigação judicial eleitoral não torna o autor da ação de impugnação de mandato eletivo carecedor da demanda, por falta de interesse de agir, dada a independência desses feitos e considerada a tipicidade dos meios de impugnação da Justiça Eleitoral" (Agravo Regimental em RESP nº 25683326, Rel. Min. Arnaldo Versiani, 12/08/2011).

18."Consoante jurisprudência desta Corte Superior, as normas de cunho processual aplicam-se imediatamente, 


\section{Conexão e riscos de decisóes conflitantes no processo eleitoral. $\mathrm{Um}$ avanço da reforma}

A última reforma eleitoral introduziu o novo art. 96-B na Lei Eleitoral (Lei no 9.504/97) para definir, no caput, que: "Serão reunidas para julgamento comum as ações eleitorais propostas por partes diversas sobre o mesmo fato" e "sendo competente para apreciá-las o juiz ou relator que tiver recebido a primeira". Cria-se regra expressa para reconhecimento de conexão e reunião de processos. Conexão enseja determinação e prorrogação de competência, pela reunião de processos, a evitar incompatibilidade lógica e prática entre julgados.$^{19}$ É o que está, na essência, definido no novo dispositivo: reconhecendo-se a existência de conexão, os processos devem ser reunidos. Há múltiplas questões controvertidas em torno da inovação.

A começar pelo próprio conceito de conexão. $\mathrm{O} C P C / 73$, art. 103, reputa conexas duas ações que tenham o mesmo objeto ou causa de pedir. Há, no CPC/73, um espaço demasiadamente amplo para aferir conexidade. ${ }^{20}$ Aliás, sequer há coesão da doutrina em torno do conceito de conexão. ${ }^{21}$ Já o NCPC deu um tratamento mais flexível, como será visto adiante. Importante, em um primeiro momento, relembrar os conceitos elementares na identificação de pontos de contatos entre demandas que apontam para a necessidade de reunião. A Lei Eleitoral agora fala em identidade de fatos; o CPC/73 e o NCPC em objeto e causa de pedir.

Para o que interessa ao artigo, por objeto mediato sempre se entendeu que se tratava do pedido. ${ }^{22}$ E o pedido é, na expressão chiovendiana, o bem da vida. O pedido imediato (eficácia preponderante) é um elemento estranho para aferir conexão. Em relação à causa de pedir, só interessa para fins de conexão a remota (narrativa fática).23 A causa de pedir próxima (fundamentação jurídica) também é algo indiferente para aferir conexidade. De lado os aspectos terminológicos (um tanto controvertidos em doutrina), importante perceber que a conexão

apanhando o processo no estágio em que se encontram. Submetem-se, porém, ao princípio tempus regit actum: conquanto as leis processuais sejam aplicáveis de imediato, devem ser respeitados os atos realizados sob o império da legislação anterior" (STJ, AgRg no REsp no 1277644/SP, Rel. Ministra Regina Helena Costa, Quinta Turma, julgado em 18.3.2014, DJe de 21.3.2014).

19. LADEIRA, Ana Clara Viola. Identificação da conexão e da correta aplicação de seus efeitos. In: Revista de Processo. v. 238, ano 39. São Paulo: Editora RT, dez. 2014, pp. 74 e 78.

20. BARBOSA MOREIRA, Jose Carlos. A conexão de causas como pressuposto da reconvenção. São Paulo: Saraiva, 1979, p. 125. Importa reconhecer que "não existe um conceito universal (lógico-jurídico) de conexão, cabendo ao direito positivo a sua definição". Citando Fredie Didier Jr.; LADEIRA, Ana Clara Viola. Identificação da conexão e da correta aplicação de seus efeitos. In: Revista de Processo. v. 238, ano 39. São Paulo: Editora RT, dez. 2014, p. 67.

21. Para as teorias em torno da conexão, conferir OLIVEIRA NETO, Olavo de. Conexão por prejudicialidade. São Paulo: Revista dos Tribunais, 1994, p. 62.

22." (...) o objeto do processo consiste exclusivamente no pedido formulado pelo demandante. É ali que reside a pretensão cujo reconhecimento e satisfação o demandante quer” (DINAMARCO, Cândido Rangel. Instituições de Direito Processual Civil. 2 vol. 3. ed. São Paulo: Malheiros, 2003, p. 143).

23."(...) basta a identidade da causa de pedir remota, isto é, dos fatos, para justificar a conexão que possibilita a reunião de duas causas” (GRECO FILHO, Vicente. Direito processual civil brasileiro. v. 1, 20. ed. São Paulo: Saraiva, 2007, p. 218). 
pode ser flagrada pela identidade do bem da vida (objeto) ou pelos fatos. ${ }^{24}$

$\mathrm{Na}$ linha da melhor doutrina, ${ }^{25}$ a jurisprudência já reconhecia uma boa dose de flexibilidade para considerar presentes os requisitos para o reconhecimento de conexão. Bastava o risco de decisóes conflitantes. ${ }^{26}$ Com o NCPC o risco de decisões conflitantes (conexão por prejudicialidade), expressamente, é requisito autônomo para reunião de demandas para julgamento conjunto (art. 55, $\left.\$ 3^{\circ}, \mathrm{NCPC}\right) .{ }^{27}$

O importante é que a reforma da Lei Eleitoral, com o art. 96-B, põe o processo eleitoral em sintonia com regras inteligentes sobre reunião de processos para julgamento conjunto, privilegiando os princípios da celeridade, da economia processual, e, especialmente, da segurança jurídica. Trata-se de importante passo para superar uma jurisprudência eleitoral de reduzido teor de racionalidade.

Antes da vigência do novo art. 96-B, com alguns poucos e recentes julgados dissonantes, o TSE sustentava a ausência (definida em abstrato) de relação (ou ausência de influência) entre as diversas ações eleitorais típicas que podiam conduzir à cassação.28 Para sustentar esta ausência de relação, o TSE entendia que as ações típicas (AIJE, AIME e RCED) tinham sempre abstratamente avaliadas - causas de pedir próprias e consequências jurídicas distintas. A orientação tinha premissas jurídicas equivocadas.

A identidade de causas de pedir (substrato factual) só é aferível a partir do cotejo entre casos concretos. Uma AIJE e uma AIME podem ou não ter identidade de causas de pedir. Em abstrato há molduras de causas de pedir dedutiveis, mas as causas de pedir efetivamente deduzidas só podem ser identificadas à luz de casos concretos. É uma impropriedade processual defender, em abstrato (em desprezo ao critério casuístico), a ausência de identidade entre estas açôes.

Idêntica conclusão em relação à existência de consequências jurídicas distintas. $\mathrm{O}$ pedido mediato (relevante para configurar conexão) nas ações de cassação, correndo o risco de dizer o óbvio, é a cassaçãa ${ }^{29} \mathrm{E}$ só pode ser esta a consequência jurídica da qual trata a orientação do TSE.

24. Um bom texto sobre estes conceitos e a conexão está em MONIZ DE ARAGÃO, Égas Dirceu. Conexão e tríplice identidade. In: Revista Ajuris. Porto Alegre: AJURIS, 1983, n. 28.

25. "(...) leva à conclusão de que basta a identidade da causa de pedir remota, isto é, dos fatos, para justificar a conexão que possibilita a reunião de duas causas. A identidade absoluta da causa de pedir, englobando a causa de pedir próxima e a remota, levaria quase sempre a uma inaplicabilidade do dispositivo." (GRECO FILHO, Vicente. Direito processual civil brasileiro. v. 1, 20. ed. São Paulo: Saraiva, 2007, p. 218)

26. "A avaliação da conveniência do julgamento simultâneo será feita caso a caso, à luz da matéria controvertida nas ações conexas, sempre em atenção aos objetivos almejados pela norma de regência (evitar decisóes conflitantes e privilegiar a economia processual)" (REsp 1366921/PR, Rel. Min. Ricardo Villas Bôas Cueva, $3^{\text {a }}$ t., $13 / 03 / 2015)$

27. Há quem identifique também neste dispositivo conexidade (OLIVEIRA, Bruno Silveira de. In DIDIER JR., Fredie, in WAMBIER, Teresa Arruda Alvim; DIDIER JR., Fredie; TALAMINI, Eduardo, DANTAS, Bruno. Breves Comentários ao novo Código de Processo Civil, São Paulo: RT, 2015, p. 222).

28. "O recurso contra expedição de diploma (RCED), a Ação de Investigação Judicial Eleitoral (AIJE) e a Ação de Impugnação de Mandato Eletivo (AIME) possuem causas de pedir própria e consequência jurídica distinta. Assim, o julgamento favorável ou desfavorável de cada uma dessas ações não influencia no trâmite uma das outras" (TSE, AREspe 26.276/CE, Rel. Min. Marcelo Ribeiro, 7.8.2008; REspe 28.015/RJ, Rel. Min. José Delgado, 30.4.2008).

29. O pedido da AIJE é de cassação e inelegibilidade (art. 22, XIV, LC 64/90). As representações também cassam e a inelegibilidade decorre de efeito secundário da sentença (art. 1º, § 1º “j”, LC 64/90). Não há, pois, 
A aferição em torno da conexão, portanto, só pode ser adequadamente realizada à luz dos casos concretos. ${ }^{30} \mathrm{O}$ critério apriorístico e abstrato do TSE (nunca há conexão entre as diversas ações típicas...) é, para insistir, processualmente inadequado. ${ }^{31}$

Agora o art. 96-B determina a reunião, por conexão, das ações eleitorais que tratam dos mesmos fatos. Resolve o problema gerado pela orientação anterior. Embora o dispositivo fale em identidade de fatos, o correto é fazer uma leitura da pertinência da reunião à luz da jurisprudência do STJ agora incorporada pelo NCPC (art. 55, §3): basta o risco de decisóes conflitantes. É o caso de usar o dispositivo do NCPC para enriquecer a regra de conexão da Lei Eleitoral, por aplicação subsidiária (e não supletiva; válida apenas para colmatar lacunas), como manda o NCPC (art. 15 do NCPC). ${ }^{32}$ De uma forma ou de outra, o art. 96-B é, sem dúvida, instrumento útil de viragem da orientação prevalente atual.

Para registrar um detalhe relevante, no atual CPC a competência é deslocada para o juiz que primeiro despachou a demanda conexa (art. 106). ${ }^{33}$ Para o NCPC, valerá o primeiro registro ou distribuição da inicial para prevenir o juízo (art. 59). A propósito, esta regra do NCPC (prevenção pela distribuição; não pelo despacho) está de acordo com o sistema das ações coletivas (art. $5^{\circ}, \$ 3^{\circ}$, Lei da ação Popular e art. $17^{\circ}, \$ 5^{\circ}$ Lei da Ação Civil Pública). Não obstante, o art. 96-B definiu que a competência será fixada pelo recebimento (despacho). Não há espaço para aplicação subsidiária ou supletiva.

discrepância de objetos nas ações que podem conduzir à cassação do mandato. Todas redundam em cassação e inelegibilidade por oito anos. E é necessário considerar que nestas ações há uma tipicidade de sanções que condicionam a formulação dos pedidos. Consequência desta natureza ope legis destas sanções, sequer há necessidade de pedido expresso (JORGE, Flávio Cheim e RODRIGUES, Marcelo Abelha. Manual de Direito Eleitoral. São Paulo: RT, 2014, pp. 319 e 397). As representações do art. 41-A e do art. 73 contêm ainda pedido de imposição de multa - o que pode indicar continência.

30. Há bons julgados com este reconhecimento, ainda que isolados: "Sabe-se que o Tribunal Superior Eleitoral tem reiteradamente afastado a litispendência entre os feitos eleitorais, por considerá-los autônomos, com causas de pedir próprias e consequências distintas. Esse entendimento, todavia, não pode ser aplicado de forma generalizada e abstrata, sob pena de fugir do real significado da litispendência, que somente pode ser apurada no caso concreto, tudo a depender da delimitação feita pelo autor da ação, pois, embora tenham causas de pedir próprias, há certa identidade entre seus fundamentos jurídicos" (TRE-ES, AIME 2247 ES , Relator: Ricardo Almagro Vitoriano Cunha, J. 15/05/2013).

31. Como está neste julgado, entre tantos: "As ações eleitorais são autônomas, com causas de pedir diversas, sendo inviável o reconhecimento, seja de conexão, seja de continência entre elas” (Agravo Regimental em Recurso Especial Eleitoral no 36277, Rel. Min. Ricardo Lewandowski, J. 10/05/2010).

32. Sobre aplicação supletiva e subsidiária do NCPC ao processo eleitoral, vale conferir o que escreveram Teresa Arruda Alvim Wambier, Maria Lúcia Lins Conceição, Leonardo Ferres da Silva Ribeiro e Rogério Licastro Torres de Mello: "O legislador disse menos do que queria. Não se trata somente de aplicar as normas processuais aos processos administrativos, trabalhistas e eleitorais quando não houver normas, nestes ramos do direito, que resolvam a situação. A aplicação subsidiária ocorre também em situações nas quais não há omissão. Trata-se, como sugere a expressão 'subsidiária', de uma possibilidade de enriquecimento, de leitura de um dispositivo sob outro viés, de extrair-se da norma processual eleitoral, trabalhista ou administrativa um sentido diferente, iluminado pelos princípios fundamentais do processo civil. A aplicação supletiva é que supõe omissão. Aliás, o legislador, deixando de lado a preocupação com a própria expressãa, precisão da linguagem, serve-se das duas expressóes. Não deve ter suposto que significam a mesma coisa, se não, não teria usado as duas. Mas como empregou também a mais rica, mais abrangente, deve o intérprete entender que é disso que se trata" (Primeiros comentários ao Novo Código de Processo Civil: Artigo por artigo. São Paulo: RT, 2015, p. 75).

33. O art. 286 do NCPC (art. 253 do CPC) define que serão distribuídas por dependência as ações de qualquer natureza quando se relacionarem por conexão, continência ou prejudicialidade com outra já ajuizada (incisos I e III). 


\subsection{A reunião de processos em instâncias diferentes. A conexão ineficiente da reforma. Suspensão por prejudicialidade}

Outro ponto importante do novo art. 96-B é a obrigatoriedade de reunião dos processos. $\mathrm{O}$ dispositivo fixa que os processos serão reunidos. O Novo CPC, na mesma medida, eliminou a dúvida em torno da discricionariedade na reunião de processos conexos. $\mathrm{O} \mathrm{CPC} / 73$, art. 105, consignava que o juiz poderia reunir os processos conexos. O STJ reconhecia o caráter facultativo. ${ }^{34}$ Agora está que os processos serão reunidos (art. 55, $\S 1^{\circ}$ ). Há obrigatoriedade de julgamento simultâneo (simultaneus processus). ${ }^{35}$ A matéria, inclusive, é cognoscível de ofício. ${ }^{36}$

Esta obrigatoriedade, no entanto, deve ser ponderada, especialmente no Direito Eleitoral, à luz dos princípios da efetividade e da celeridade. Os processos não podem ser reunidos quando houver ofensa aos princípios da efetividade e da duração razoável do processo. Necessário esclarecer que esta necessária ponderação não equivale à facultatividade. A síntese é: a reunião dos processos se impõe sempre nos casos de conexão, mas desde que não haja ofensa ao princípio da efetividade e da celeridade.

Com estas consideraçóes deve ser lido o $₫ 2^{\circ}$ do art. 96-B. O dispositivo determina a reunião dos processos, ainda que estejam em instâncias diferentes. É dizer: se a AIJE já estiver julgada, a AIME em trâmite será remetida para a instância superior para julgamento simultâneo. Trata-se de um equívoco que a interpretação sistemática deve corrigir.

A Súmula 235 do STJ define que "a conexão não determina a reunião de processos, se um deles já foi julgado" ${ }^{37}$ É assim também no NCPC (art. 55, $§ 1^{\circ}$ ). Parece óbvio. O próprio TSE (nos poucos e recentes casos em que reconhecia conexão) vedava a reunião quando um dos processos já tivesse sido julgado (ou mesmo em fases processuais distintas) ${ }^{38}$

Não se deve deixar de considerar que o efeito jurídico da conexão atende também a um

34. EDcl no AgRg no REsp 1193525/RJ, Rel. Min. Humberto Martins, 2a t., 04/12/2012.

35. "A nova dicção legal (...) consigna claramente tratar de um dever judicial (diz, peremptoriamente, que os processos de ações conexas serão reunidos para decisão conjunta)," OLIVEIRA, Bruno Silveira de. In DIDIER JR., Fredie, in WAMBIER, Teresa Arruda Alvim; DIDIER JR., Fredie; TALAMINI, Eduardo, DANTAS, Bruno. Breves Comentários ao novo Código de Processo Civil, São Paulo: RT, 2015, p. 222. No mesmo sentido: AMARAL, Guilherme RIZZO. Comentários às alterações do novo CPC. São Paulo: RT, 2015, p. 112-113. Defendendo a obrigatoriedade da reunião já no ambiente do CPC/73, OLIVEIRA, Bruno Silveira de. Conexidade e efetividade processual. São Paulo: RT, 2008, p. 170.

36. "A conexão é causa de modificação de competência, não um critério de fixação de competência. Envolve, pois, matéria de ordem pública, examinável de ofício, nos moldes da autorização legal contida no art. 301, §40" (STJ, CC n ${ }^{\circ} 25.735 / \mathrm{SP}, 1^{\mathrm{a}}$ seção, Rel. Min. Nancy Andrighi, 7/4/2000).

37. E basta o julgamento; não é necessário o trânsito em julgado: "O fato de ainda não ter ocorrido o trânsito em julgado da sentença proferida na açâo ordinária não afasta a aplicação do entendimento já sumulado pelo STJ de que a possivel existência de conexão ou continência não determina a reunião dos processos, quando já proferida a sentença num deles" (TRF4, AI nº 0013979 0.2012.404.0000, 3ª t., Rel. Des. Fernando Quadros da Silva, 14/3/2013).

38. Importante reconhecer que desde 2013 flagrava-se um movimento do TSE em favor do reconhecimento de conexão, como no exemplo: "Na bipótese, não há conveniência, porquanto os autos supostamente conexos encontram-se em fases processuais distintas" (Recurso Ordinário n 151449, Rel. Min. Laurita Vaz, Data 07/08/2013). No mesmo sentido: "Não é possível determinar-se a conexão de feitos, em casos em que um deles já tenha sido julgado pelo Tribunal” (TRE-MG, RCED n 71109, Rel. Alberto Diniz Júnior, 9/7/2013). 
pressuposto de economia processual.$^{39}$ É como está na lógica que autoriza a prorrogação de competência. Assim, é necessário separar a conexão de seu efeito jurídico (reunião de processos). Mesmo constatada a conexão, o efeito jurídico não se justifica se já tiver havido, em relação a qualquer um, julgamento na instância de origem. Isso significa que não se pode reunir processos se um já estiver pronto para julgamento e o conexo estiver ainda no início. Haveria violação à efetividade e à celeridade. ${ }^{40}$

A jurisprudência terá de conformar um entendimento que tempere uma regra que tem orientação confrontante com a própria lógica fundante do dispositivo.

\subsection{Conexão e reunião dos processos com o Corregedor, competente para julgamento da AIJE}

Nas eleições municipais, a competência para julgamento das AIJE's é dos juízes eleitorais de $1^{\circ}$ grau de jurisdição. Nas eleiçôes estaduais e presidenciais a competência é do Corregedor - dos TRE's e do TSE, respectivamente. Há sérias dúvidas em torno da constitucionalidade da regra que entrega competência exclusiva para Corregedor para todas as AIJE's. Há quem identifique ofensa ao princípio do juiz natural. ${ }^{41}$

É importante lembrar que a competência do Corregedor nas eleições estaduais e presidenciais não é propriamente para julgar, mas apenas para instruir a $\mathrm{AIJE}$; funciona como relator (art. 22, I, LC 64/90). A competência para julgamento do mérito da AIJE é sempre do plenário da corte (art. 22, XII, LC 64/90).

De qualquer forma, a prevenção é regra de distribuição de ações e recursos. O Corregedor, relator da ação (AIJE), é prevento para todas as demais açōes que tratem dos mesmos fatos (art.96B). O problema é que a competência do Corregedor é absoluta. E apenas as competências relativas autorizam modificação de competência, por prevenção, nos casos de conexão e continência. ${ }^{42}$

Ainda assim a conexão impõe o julgamento simultâneo, mas a prevenção teria de ser ignorada, com a reunião sempre no Corregedor. É dizer: mesmo que a AIJE tenha sido distribuída depois, Representações e a AIME que já tenham sido distribuídas devem ser reunidas para julgamento conjunto perante o Corregedor. ${ }^{43} \mathrm{~A}$ concentração de todas as ações no Cor-

39. WAMBIER, Luiz Rodrigues; TALAMINI, Eduardo. Curso avançado de processo civil: Teoria Geral do Processo e Processo de Conhecimento. 11. ed. São Paulo: Revista dos Tribunais, 2010, p. 212.

40. OLIVEIRA, Bruno Silveira de. Conexidade e efetividade processual. São Paulo: RT, 2008, p. 167-171. No mesmo sentido, reconhecendo que a reunião dos processos não justifica se houver sacrifício à celeridade e à economia processual, LADEIRA, Ana Clara Viola. Identificação da conexão e da correta aplicação de seus efeitos. In: Revista de Processo. v. 238, ano 39. São Paulo: Editora RT, dez. 2014, p. 68.

41. JORGE, Flávio Cheim; RODRIGUES, Marcelo Abelha. Manual de Direito Eleitoral. São Paulo: RT, 2014, pp. 321-322.

42. STJ, MS 9.299/DF, Rel. Ministro Teori Zavascki, $1^{\text {a }}$ seção, 20/09/2004. É como está no art. 54 NCPC: "A competência relativa poderá modificar-se pela conexão ou pela continência, observado o disposto nesta Seção”.

43. Assim é a orientação da jurisprudência: "A competência para processamento e julgamento de mandado de segurança é (...) insuscetivel de sofrer modificação. Verificada a existência de conexão do mandamus com açôes ordinárias de distribuição mais antiga, os efeitos da conexão laborarão em sentido inverso, produzindo a modificação da competência para apreciar as ações ordinárias" (TRF-4 - CC: 441 PR 2009.04.00.000441-0, Rel.: Valdemar Capeletti, 2a seção, 08/05/2009). 
regedor reforça a necessidade de o TSE sindicar a constitucionalidade da regra de distribuição em face do princípio do juiz natural.

Também não se pode desconsiderar que uma AIJE possa ser utilizada para burlar o princípio do juiz natural. Proposta uma Representação que possa conduzir à cassação (art. 30-A, por exemplo), a propositura posterior de uma AIJE (conexa ou continente) atrairia ao Corregedor a competência e, com isso, suprimiria competência do Juiz auxiliar a quem havia sido distribuído o processo original.

De qualquer forma, as regras de conexão sempre atendem a um postulado de efetividade. Se a reunião de processos estiver em desacordo com o vetor da efetividade e da duração razoável do processo, a conveniência deve ser avaliada em atenção ao critério casuístico (conferir tópico 3.1). Não se deve perder de vista que os processos de cassação de mandato devem estar julgados, em todas as instâncias, no máximo em um ano. ${ }^{44} \mathrm{O}$ mesmo raciocínio vale quando houver tentativa de burla ao princípio do juiz natural. O princípio da adequação autoriza um juízo de conveniência da reunião (orientado pelo respeito aos princípio da efetividade e da celeridade). ${ }^{45}$

Uma solução alvitrada pela doutrina e por parcela da jurisprudência é a suspensão do processo prejudicialidade (art. 265, IV, CPC; 313, V, NCPC) ${ }^{46}$ Não parece a melhor solução. É o caso de deixar que avancem os dois processos. Um dos principais traços distintivos do Direito Eleitoral, para insistir, é o princípio da celeridade. ${ }^{47}$

\subsection{A AIME se submete às regras de prevenção. $O$ status constitucional não subverte as regras de mudança de competência}

Não há nenhuma particularidade juridicamente relevante que exclua a AIME das regras de prevenção indicadas neste texto. Não obstante, no TSE já se decidiu que "não há como extinguir a AIME, ação de indole constitucional, pela mera circunstância da existência de ações anteriores". ${ }^{48}$ Não é possível concordar. Os fenômenos da litispendência e da coisa julgada (e da conexão) não excluem de seus campos de abrangência as ações de indole constitucional.

As ações de indole constitucional estão previstas na Constituição Federal especialmente para dificultar a supressão do remédio processual pelo legislador ordinário, como já explicava

\footnotetext{
44. Lei 9.504/97."Art. 97-A. Nos termos do inciso LXXVIII do art. 50 da Constituição Federal, considera-se duração razoável do processo que possa resultar em perda de mandato eletivo o período máximo de 1 (um) ano, contado da sua apresentação à Justiça Eleitoral. $§$ 1o A duração do processo de que trata o caput abrange a tramitação em todas as instâncias da Justiça Eleitoral".

45. DIDIER JR., Fredie; ZANETI JR., Hermes. Curso de direito processual civil» Processo coletivo. $4^{\mathrm{a}}$ Ed. Vol. 4. Salvador: Editora PODIVM, 2009, p. 170.
}

46. DIDIER JR., Fredie; ZANETI JR., Hermes. Curso de direito processual civil: Processo coletivo. $4^{\mathrm{a}}$ Ed. Vol. 4. Salvador: Editora PODIVM, 2009, p. 175.

47. JARDIM, Torquato. Direito Eleitoral Positivo. 2. ed. Brasília: Brasília Jurídica, 1998, p. 151. No TSE, o prazo certo do mandato é reconhecido como fator determinante na conformação da tutela jurisdicional: "As peculiaridades do processo eleitoral - em especial o prazo certo do mandato - exigem a adoção dos procedimentos céleres próprios do Direito Eleitoral, respeitadas, sempre, as garantias do contraditório e da ampla defesa" (TSE, Res. n² 21.634, de 19.2.2004, rel. Min. Fernando Neves).

48. Trecho do voto no REspe nº 254, rel. Min. Henrique Neves, 20.11.2014. 
BUZAID ${ }^{49}$ O bem jurídico tutelado pela AIME (normalidade e legitimidade das eleições; sem abusos) pode ser tutelado em uma AIJE, em uma Representação ou em qualquer outra ação eleitoral típica (ou atípica). Basta que estas ações contenham abuso (fato que configure abuso lato sensu) como causa de pedir remota e uma sanção típica de cassação. Neste aspecto não há qualquer relevância em relação à sede de previsão (constitucional ou infraconstitucional) dos instrumentos processuais aptos a concretizar direitos materiais (inclusive os direitos materiais fundamentais).

No referido julgamento do TSE consignou-se que "na AIME - muito mais do que em outras açôes eleitorais - sobressai a tutela da legitimidade do pleito". Ora, a tutela de legitimidade do pleito pode estar adequadamente veiculada em qualquer outra ação eleitoral (ação processual abstrata), indistintamente. A previsão constitucional da AIME não altera esta conclusão. Não há nada na AIME que não haja em uma AIJE ou mesmo em uma Representação que possa conduzir à cassação.

A Constituição Federal assegura a normalidade e legitimidade das eleições, impedindo o abuso (art. 14, $\left.\S 9^{\circ}\right)$. Assim, o fundamento processual da tutela de legitimidade do pleito está na própria Constituição Federal (art. $5^{\circ}, \mathrm{XXXV}$ ), a prescindir de qualquer outras expressa previsão constitucional ou infraconstitucional. ${ }^{50}$ Todos os direitos materiais são acionáveis em juízo por garantia constitucional à adequada tutela jurisdicional. Há um direito fundamental à efetividade da tutela jurisdicional. ${ }^{51}$ Não fosse a AIME, seria uma $\mathrm{AIJE} \mathrm{E}^{52}$ ou qualquer outra técnica de tutela que fosse a "expressão realizadora da ação de direito material", para usar uma expressão de Ovídio BAPTISTA DA SILVA.53

O mandado de segurança também tem índole constitucional. Atualmente, no entanto, não oferece nada que já não esteja contemplado pela tutela das obrigaçóes de fazer e não fazer. E parece evidente que a sede constitucional não outorga ao MS nenhuma técnica processual que o CPC (sede infraconstitucional) não pudesse outorgar. ${ }^{54} \mathrm{O}$ abuso de poder não ficaria imune

49." qualquer outra espécie de proteção conferida por lei ordinária poderia desaparecer ou ser diminuída ao fluxo das deliberaçóes do Congresso, sujeito às vicissitudes das maiorias eventuais" (BUZAID, Alfredo. Do mandado de segurança. São Paulo: Saraiva, 1989. p. 193).

50. Ao tratar da AIME, COSTA, Adriano Soares da: "Se se cria uma ação, é porque há algum interesse anterior a merecer proteção" (Instituições de Direito Eleitoral. 9a ed. Belo Horizonte: Fórum, 2013, p. 396). Este interesse anterior (direito material) pode ser protegido por ação com sede constitucional ou infraconstitucional. A resposta que Adriano oferece à tese de Konder Comparato sobre a "inexistência" da AIME elucida muito bem o tema.

51. MARINONI, Luiz Guilherme. O direito à efetividade da tutela jurisdicional na perspectiva da teoria dos direitos fundamentais. In: Revista de Direito Processual Civil. n. 28, abr/jun. de 2003, ed. Gênesis, p. 298/338.

52. Em alguma medida a AIJE também tem status constitucional: "É evidente, portanto, que a ação de investigação judicial eleitoral tem assento cativo no art. 14, §9 9 , da CF/1998, pois é a técnica que o legislador encontrou de criar situaçóes de inelegibilidade que visem a proteçâo da legitimidade e da normalidade contra a influência do poder econômico ou o abuso do exercício de função (...)" (JORGE, Flávio Cheim; RODRIGUES, Marcelo Abelha. Manual de Direito Eleitoral. São Paulo: RT, 2014, p. 319).

53. Curso de Processo Civil, vol. I. Porto Alegre: Fabris, 1993, p. 321.

54. TALAMINI, Eduardo, explica que não se pode admitir que, por exemplo, a força mandamental “a dada ação fosse algo que só a Constituição pudesse atribuir" (As origens do mandado de segurança na tradição processual Luso-brasileira. In: Aspectos Polêmicos e atuais do Mandado de Segurança. BUENO, Cássio Scarpinella; ALVIM, Eduardo Arruda; Teresa Arruda Alvim Wambier (Coords.). São Paulo: RT, 2002, p. 312). 
ao controle jurisdicional se houvesse a supressão do inciso LXIX do art. $5^{\circ}$ da Constituição Federal. E o mandado de segurança, abstratamente considerado, não é mais (nada mais) em relação a uma demanda contra a administração que tenha um pedido (imediato) mandamental.

Para insistir, se não houvesse previsão alguma de natureza processual (constitucional ou infraconstitucional), todos os direitos materiais tutelados hoje tutelados pela AIME (ou pela AIJE) estariam assegurados pela direito fundamental à efetividade da tutela jurisdicional. Caberia ao Judiciário conceber técnicas adequadas. ${ }^{55}$ Supor o contrário é imaginar que poderia haver a garantia constitucional da legitimidade das eleições sem instrumentos processuais aptos à proteção, à tutela deste direito, o que é inconcebível.

Por tais razões não é possível concordar com o raciocínio jurídico do precedente do TSE. Não é porque a AIME está na Constituição que deve ser reconhecida como o "principal meio processual para se buscar a desconstituição do mandato" (Resp 254). A AIME é apenas mais um meio processual. O meio processual principal para desconstituir mandatos (leia-se aqui: técnicas processuais adequadas) poderia estar na legislação infraconstitucional. A sede constitucional, portanto, só tem a relevância apontada por BUZAID (dificultar a supressão pelo legislador infraconstitucional). Aliás, também para reiterar, como há meios processuais hábeis na legislação infraconstitucional (AIJE e Representações), a desconstituição do mandato prescinde da AIME em sede constitucional.

Tanto é assim mesmo que o status constitucional do mandado de segurança nunca foi tal a provocar a derrogação da regra de litispendência. O Superior Tribunal de Justiça reconhece a necessidade de extinguir mandado de segurança proposto em litispendência com ação ordinária anteriormente ajuizada.56 É o entendimento que deve prevalecer no TSE quando houver AIME em litispendência com a AIJE. Idêntica conclusão em relação à conexão.

Há outro problema em torno desta vis attractiva universal em torno da AIME (apenas porque em sede constitucional), tal qual como cogitada pelo TSE. As Representações e a AIJE comportam um pedido inibitório cumulado (art. 73, § 40, Lei Eleitoral; art. 22, I, "b", Lei de Inelegibilidades) ${ }^{57}$ Imaginar que tudo deva ser reunido no juízo competente para a AIME cria a transferência da demanda para quem não apreciou a tutela inibitória sumária (antecipada). Os juízes das inibitórias seriam, depois, substituídos pelo juiz da AIME (havendo conexidade).

Ainda tratando de pedido de cassação cumulado com uma inibitória, o NCPC admite expressamente a sentença parcial de mérito (art. 356). Se a inibitória cumulada prescindir de

55."Se o dever do legislador editar o procedimento idôneo pode ser reputado descumprido diante de determinado caso concreto, o juiz, diante disso, obviamente não perde o seu dever de prestar a tutela jurisdicional efetiva. Por tal razão, o juiz tem o dever de interpretar a legislação à luz do direito fundamental à tutela jurisdicional, estando obrigado a extrair da regra processual, sempre com a finalidade de efetivamente tutelar os direitos, a sua máxima potencialidade". (MARINONI, Luiz Guilherme. O direito à efetividade da tutela jurisdicional na perspectiva da teoria dos direitos fundamentais. In: Revista de Direito Processual Civil. n. 28, abr/jun. de 2003, ed. Gênesis, p. 313).

56. "Constatada a identidade de partes, causa de pedir e pedidos entre o presente mandamus e a ação ordinária [ajuizada anteriormente], resta configurada a litispendência nos termos do art. $301, \$ 2 .^{\circ}$, do Código de Processo Civil. Processo extinto sem julgamento de mérito" (STJ, MS: 12640 DF 2007/0034634-5, Rel. Min. Marilza Maynard, $3^{\mathrm{a}}$ seção, J. 04/12/2014)

57. Não se diga que a cumulação na AIJE seria impossível, por força do art. Art. 292, § 1º II, CPC (art. 327, $\S 1^{\circ}$, II, NCP). É que a inibitória, quando relacionada aos mesmos fatos do pedido de cassação/inelegibilidade, também é de competência do Corregedor - que tem a competência de suspender o ilícito (art. 22, I, "b", LC 64/90). 
instrução (o que é regra, por ausência de manifestação sobre dano e culpa) e, por isso, estiver em condições de imediato julgamento, a decisão parcial de mérito se impõe (art. 356, II). ${ }^{58} \mathrm{~A}$ valer o entendimento do TSE, pendente a parcela do pedido da AIJE que diz com a cassação, a propositura posterior de AIME (ainda que contida na AIJE) modificaria a competência.

Por inúmeros motivos não é possível sustentar que a AIME não se submete a qualquer regra de modificação de competência ou de litispendência diversa em razão do singelo motivo de ter sede constitucional.

\section{Continência, litispendência e coisajulgada. $\mathrm{O}$ microssistema das ações coletivas para as açóes eleitorais}

Tal qual no direito comparado, nunca deixou de se reconhecer que o bem visado nas açóes eleitorais de cassação (verdade eleitoral; lisura do processo) possui caráter supraindividual (tutela da normalidade das eleições). ${ }^{59}$ Exatamente por isso é inegável a relação entre Direito Eleitoral e o microssistema do processo coletivo. ${ }^{60}$

A supraindividualidade orientou o Código Eleitoral de 1965 a reconhecer a qualquer eleitor legitimidade ativa para impugnar o registro de candidatura, a partir da racionalidade própria das ações populares (art. 97, $₫ 3^{\circ}$ ). Esta legitimidade ativa extraordinária foi suprimida com a LC 05/70. ${ }^{61}$ Idêntica discussão houve em torno da delimitação dos legitimados à propositura de AIME. A Constituição Federal não enunciou quem estaria autorizado a figurar no pólo ativo. Muitos eram, no pós-88, os que defendiam aplicação das regras de legitimação ativa da ação popular para a AIME.$^{62}$ Conformou-se, no entanto, uma jurisprudência restritiva, fazendo coincidir na AIME o mesmo rol de legitimados definidos para a AIJE na LC

58. Para muitos já é assim com o CPC vigente. MITIDIERO, Daniel Francisco, Direito fundamental ao julgamento definitivo da parcela incontroversa: uma proposta de compreensão do art. $273, \S 6^{\circ}$, do CPC, na perspectiva do direito fundamental a um processo sem dilações indevidas (art. $5^{\circ}$, LXXVII, da CF/1988). In: Revista de Processo. n. 149. São Paulo, RT, jul. 2007.

59. Como está muito bem defendido, a partir de ricas referências do direito comprado, por PEREIRA, Rodolfo Viana. Tutela Coletiva no Direito Eleitoral. Controle Social e Fiscalização das Eleições. Lumen Juris, 2008, p. 129. FICHTNER, José Antônio. Impugnação de mandato eletivo. Rio de Janeiro: Renovar, 1998, p. 32. RAMAYANA, Marcos. Direito Eleitoral, $8^{a}$ ed., Rio de Janeiro: Impetus, 2008, p. 491.

60. É importante ressalvar aqui que esta relação com o microssistema dos processos coletivos não abrange todas as ações eleitorais. Não é possível, por exemplo, falar supraindividualidade em um pedido de direito de resposta.

61. Para um panorama em torno deste debate, PEREIRA, Luiz Fernando C. O reconhecimento de ofício da inelegibilidade. In: Revista Brasileira de Direito Eleitoral - RBDE. ano 1, n. 1. Belo Horizonte: Fórum, p. 157-197, jul./dez. 2009. Para conferir as críticas à restrição do rol de legitimados: PINTO, Djalma. Direito Eleitoral: improbidade administrativa e responsabilidade fiscal - noções gerais. $3^{a}$ ed. São Paulo: Atlas, 2006, pág. 169.

62. Entre outros, FRANCISCO, Caramuru Afonso. Dos abusos das eleições. São Paulo: Juarez de Freitas, 2002, p. 179; MENDES, Antônio Carlos. Aspectos da ação de impugnação de mandato eletivo. In: Direito Eleitoral. VELLOSO, Carlos Mário da Silva; ROCHA, Cármen Lúcia Antunes (Coords.). Belo Horizonte: Del Rey, 1996, p. 337. 
64/90 (Partidos Políticos e Coligações, Candidatos e Ministério Público).63

A orientação que predominou não negava propriamente a supraindividualidade dos direitos subjacentes às ações eleitorais (de controle de registrabilidade e lisura do processo eleitoral). A preocupação estava (na AIRC e na AIME) com o "ajuizamento de ações temerárias, politicas e sem fundamento" ${ }^{64}$ É o argumento central na supressão da legitimidade ativa aos eleitores para a propositura de AIRC e AIME. Necessário reconhecer que, a partir de um critério de conveniência do legislador, a supraindividualidade pode conviver com limitação de legitimados (ADI, ADPF, por exemplo).

Não obstante, a supressão de legitimidade ativa nas ações eleitorais acabou afastando o Direito Eleitoral do microssistema dos processos coletivos. Tratou-se de um equívoco. A escolha do legislador/julgador em limitar a legitimidade ativa (na AIRC e na AIJE) deu-se a partir de outras (e questionáveis) premissas, sem desconsiderar o pressuposto lógico-jurídico de aproximação entre as ações eleitorais e as ações coletivas. ${ }^{65}$ Inegável, enfim, que "o direito ao devido processo eleitoral é um direito de natureza coletiva" ${ }^{66}$ Era o que já vinha sendo reconhecido em alguns precedentes mais recentes dos tribunais regionais eleitorais ${ }^{67}$

O dever de o Ministério Público assumir a titularidade de açóes eleitorais em caso de desistência pelos autores originais, inclusive em fase recursal, revela o grau de aderência com o microssistema de açóes coletivas. ${ }^{68}$ Trata-se de técnica própria dos processos coletivos, com previsão expressa na Lei da Ação Popular (art. 9º, Lei 4.717/65), aplicada subsidiariamente ao contencioso eleitoral. ${ }^{69}$

A partir da congruência de pressupostos e inúmeros pontos de contato, impunha-se que as questóes atinentes à litispendência (parcial - continência, ou total) e à coisa julgada fossem

63. Sobre o tema, conferir LEMBO, Cláudio. Participação política e assistência simples no direito eleitoral. Rio de Janeiro: Forense, 1991. Também FICHTNER, José Antônio. Impugnação de mandato eletivo. Rio de Janeiro: Renovar, 1998, pp. 39-44. E ainda RODRIGUES, Marcelo Abelha e CHEIM JORGE, Flavio. Manual de Direito Eleitoral. São Paulo: RT, 2014, p. 453. Importante lembrar que o art. 237 do Código Eleitoral outorga legitimidade ao eleitor para impugnar abusos nas eleiçóes. Disso trata COSTA, Adriano Soares da. Instituições de Direito Eleitoral, 9a ed. Belo Horizonte: Fórum, 2013, pp. 393-397.

64. CÂNDIDO, José Joel. A ação de impugnação de mandato eletivo. In: Anais do I Seminário Brasileiro de Direito Eleitoral. Porto Alegre: TRE-RS, 1990, p. 200.

65."A lisura do processo eleitoral é um bem jurídico-constitucional que ultrapassa o círculo de interesses dos atores que participam diretamente no pleito" (Pereira, Rodolfo Viana. Tutela Coletiva no Direito Eleitoral. Controle Social e Fiscalização das Eleições. Lumen Juris, 2008, p. 161).

66. JORGE, Flávio Cheim e SANTOS, Ludgero F. Liberato. As ações eleitorais e os mecanismos processuais correlatos: aplicação subsidiária do CPC ou do CDC c/c LAC. In: Revista Brasileira de Direito Eleitoral - RBDE. ano 4, n. 6. Belo Horizonte: Fórum, p. 63-81, jan/jun. 2012. No mesmo sentido, RAMAYANA, Marcos. Direito Eleitoral. 8 ed., Rio de Janeiro: Impetus, 2008, p. 491.

67. "As partes no processo eleitoral não defendem apenas interesse particular, mas sim metaindividuais, de ordem pública, assemelhando-se às ações coletivas de defesa de interesses difusos" (TRE-MS, MS no 10110, Rel. Elton Luís Nasser de Mello, 09/07/2014).

68. Agravo regimental em RESP n 35740, Rel. Min. Aldir Guimarães Passarinho, 06/08/2010.

69. "Embora não haja previsão expressa para que o Ministério Público assuma o polo ativo da demanda, tal medida é justificada pela relevância do interesse público insito na demanda e por analogia, nos art. $9^{\circ}$ da Lei 4.717/65" (GOMES, José Jairo. Direito Eleitoral. 2a ed. Belo Horizonte: Del Rey, 2008. p. 341). 
mesmo tratadas à luz da lógica própria do microssistema dos processos coletivos. ${ }^{70}$ É agora o que está nos novos parágrafos $1^{\circ}$ e $3^{\circ}$ do art. 96-B, concebidos a partir de uma racionalidade processual típica deste microssistema. Trata-se de correto pressuposto segundo o qual a coletivização da tutela jurisdicional eleitoral é instrumento inteligente de pacificação pelo processo. ${ }^{71}$

A aplicação destes novos dispositivos da Lei Eleitoral deve ser realizada no contexto hermenêutico dos processos coletivos; congruente com a lógica dos processos coletivos. ${ }^{72}$ Aqui cabe aplicação subsidiária do microssistema dos processos coletivos para enriquecer os parágrafos $1^{\circ}$ e $3^{\circ}$ do art. 96-B; para ler os dispositivos sob o viés das ações coletivas, iluminados pelos princípios processuais próprios dos direitos metaindividuais. ${ }^{73}$

70. Era o que já havia sido reconhecido por JORGE, Flávio Cheim e SANTOS, Ludgero F. Liberato: "sendo o objeto da ação eleitoral de natureza coletiva, há que se aventar sobre a aplicação subsidiária às disposições legais existentes, o microssistema processual coletivo, para resolver questões tais como reunião de processos, (litispendência e a existência de coisa julgada)". As ações eleitorais e os mecanismos processuais correlatos: aplicação subsidiária do CPC ou do CDC c/c LAC. In: Revista Brasileira de Direito Eleitoral - RBDE. ano 4, n. 6. Belo Horizonte: Fórum, p. 76, jan/jun. 2012. O artigo menciona alguns julgados da jurisprudência eleitoral que aplicaram a lógica do microssistema coletivo no Direito Eleitoral. No mesmo sentido: "A moralidade eleitoral, consistente no interesse de se preservar a lisura das eleições, tem a natureza de interesse difuso, que se confunde com o próprio interesse público. Assim, as ações de investigação judicial eleitoral (AIJE) e de impugnação de mandato eletivo (AIME), enquanto meios de controle da moralidade eleitoral, têm a natureza de ação popular. E, diante da natureza do interesse protegido, o regime da coisa julgada aplicável à AIJE e à AIME é o regime próprio da coisa julgada nas ações coletivas para a defesa de interesses difusos, regulado pelo art. 103, I, do Código de Defesa do Consumidor (Lei n 8078/90), pelo art. 16 da Lei de Ação Civil Pública (Lei nº 7347/85) c/c os seus arts. 1, IV, e 21, e pelo art. 18 da Lei de Ação Popular (Lei no 4717/65), aplicando-se supletivamente no que couber o regime do CPC" (MUSSI, Fabrício, Priotto. O regime da coisa julgada nas ações de investigação judicial eleitoral e de impugnação de mandato eletivo. In: Revista Paraná Eleitoral. v. 56, 2009, pp. 29-63).

71. Sobre a tendência de coletivização para a pacificação pelo processo, DINAMARCO, Cândido Rangel. Fundamentos do Processo Civil Moderno. Tomo II, 4a edição. São Paulo: Malheiros Editores, 2000, p. 755.

72. Antes mesmo da reforma, RODRIGUES, Marcelo Abelha e CHEIM JORGE, Flavio já chamavam a atenção para a "necessidade de se enxergar as técnicas processuais eleitorais sob a perspectiva da tutela jurisdicional coletiva" (Manual de Direito Eleitoral. São Paulo: RT, 2014, p. 283).

73. Sobre esta visão da aplicação subsidiária, Teresa Arruda Alvim Wambier, Maria Lúcia Lins Conceição, Leonardo Ferres da Silva Ribeiro e Rogério Licastro Torres de Mello. Primeiros comentários ao Novo Código de Processo Civil. Artigo por artigo. São Paulo: RT, 2015, p. 75. Para compreender os princípio do microssistema, conferir GRINOVER, Ada Pellegrini. Direito Processual Coletivo. In Direito Processo Coletivo e o anteprojeto de Código Brasileiro de Processos Coletivo. São Paulo: RT, 2007, pp. 11-15. 


\section{O reconhecimento de continência e litispendência nas ações eleitorais}

Nunca se reconheceu litispendência e continência (litispendência parcial) entre ações eleitorais que tinham por objetivo a cassação de mandato. A análise da litispendência na jurisprudência eleitoral sempre foi realizada em abstrato, a partir dos mesmos critérios utilizados para afastar conexão (conferir tópico 03 ). ${ }^{74}$ Dito de outra forma, reconhecia-se também aqui um critério apriorístico e abstrato para afastar a litispendência/continência, indiferente ao critério casuístico. Pelas razões já expostas ao tratar de conexão, a litispendência/continência só pode ser flagrada no cotejo entre duas demandas concretas, a partir da análise dos elementos próprios de identificação.

É evidente que uma AIJE - o que só se identifica a partir de elementos do caso concreto - pode reproduzir idêntica situação jurídico-substancial de uma AIME (ou de outra AIJE) proposta em momento seguinte. Em processos distintos, repete-se ação em curso, para usar a

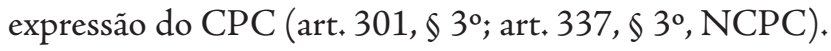

$\mathrm{Na}$ hipótese de continência, flagra-se identidade de partes e causa de pedir,"mas o pedido de uma, por sem mais amplo, abrange o das demais" (art. 104, CPC; art.56, NCPC). Trata-se sempre de litispendência parcial. ${ }^{75}$ Em verdade a relação de continência não se afere apenas em relação ao pedido. A ação continente, explica DINAMARCO, também pode ter "razões mais amplas" em relação à ação contida. ${ }^{76}$

A reorientação operada pelo art. 96-B em relação à conexão (que manda observar os fatos; o caso concreto, portanto) e a aproximação ao microssistema dos processos coletivos ( $\$ 1^{\circ}$ e $3^{\circ}$ ) devem reorientar a jurisprudência também em relação à litispendência e à continência. Noutras palavras, não há mais espaço para a utilização do método apriorístico e abstrato do TSE para refutar litispendência e continência entre ações eleitorais.

74. "O entendimento predominante nesta Corte Superior é no sentido de que não há litispendência entre a ação de impugnação de mandato eletivo e a ação de investigação judicial eleitoral, por se tratarem de demandas com causas de pedir e objetos distintos". (Recurso Especial Eleitoral n² 254, Rel. Min. Henrique Neves, 20/11/2014).

75. WLADECK, Felipe Scripes. Código de Processo Civil Anotado. CRUZ e TUCCI, José Rogério; FERREIRA FILHO, Manoel Caetano; APRIGLIANO, Ricardo de Carvalho; DOTTI, Rogéria Fagundes; MARTINS, Sandro Gilbert (Coords.). AASP-OAB/PR, 2015, p. 95.

76. DINAMARCO, Cândido Rangel. Fundamentos do Processo Civil Moderno. $6^{a}$ ed. Tomo I. São Paulo: Malheiros, 2010, p. 709. A que se considerar a questão da continência não apenas a partir do pedido, mas também da causa de pedir. Demandas eleitorais podem ter o mesmo pedido de cassação, mas podem ter causas de pedir coincidentes (sendo que uma das ações tem mais causas de pedir autônomas). Fredie Didier parece chegar à conclusão idêntica por outro caminho. Tratando de continência, sustenta que se a causa de pedir é distinta, distinto também é o pedido que se deduz a partir desta causa de pedir: "Não se pode considerar igual aquilo que é diferente (princípio lógico da não-contradição): se os atos impugnados são distintos, distintos também são os pedidos" (In: Ações concorrentes: Prejudicialidade e preliminaridade. Conexão. Suspensão do processo. litispendência. Continência. Cumulação subsidiária de pedidos. Cumulação ulterior de pedidos. Honorários advocatícios. RF 385/235). Além de reconhecer que a continência pode se dar pela discrepância de extensão das causas de pedir, WLADECK, Felipe Scripes também adverte que a continência pode ser reconhecida por uma dimensão mais ampla dos elementos subjetivos de uma demanda em relação a outra (Código de Processo Civil Anotado. CRUZ e TUCCI, José Rogério; FERREIRA FILHO, Manoel Caetano; APRIGLIANO, Ricardo de Carvalho; DOTTI, Rogéria Fagundes; MARTINS, Sandro Gilbert (Coords.). AASP-OAB/PR, 2015, p. 95). 
Para o reconhecimento de litispendência o CPC (e o NCPC) exige tríplice identidade (mesmas partes, causa de pedir e pedido). ${ }^{77}$ Boa parte da doutrina, no entanto, sempre reconheceu que a insuficiência da tríplice identidade para flagrar hipóteses de litispendência. A ideia é adotar um critério mais flexível, com a diretriz de evitar que dois processos com o mesmo objetivo tenham resultados diferentes. ${ }^{78}$ Assim também para parcela da jurisprudência ${ }^{79}$

Independentemente desta controvérsia, nas ações coletivas a litispendência/continência sempre mereceu outra leitura. Sempre bastou a identidade de causa de pedir e pedido ${ }^{80}$ Isso porque as partes atuam como substitutos processuais da coletividade, para usar uma expressão de Ada Pellegrini GRINOVER. ${ }^{81}$ Assim também nas ações eleitorais. $O$ fato de candidatos e partidos políticos terem interesse próprios, beneficiados por eventual decisão de cassação do adversário, não desnatura esta legitimidade processual coletiva. ${ }^{82}$

A litispendência e a continência são fenômenos reconheciveis através da análise do direito material subjacente. Deve haver identidade entre as pretensões de direito material. E assim, o conceito de partes, para identificação da litispendência (e da continência), deve levar em consideração a titularidade do direito material. ${ }^{83} \mathrm{Nas}$ ações eleitorais a titularidade do direito material é do eleitor; da coletividade. Apenas no plano processual é que aparecem os substi-

77. Art. 301, § 2०, CPC; art. 337, \$2 $2^{\circ}$ NCPC.

78. A chamada teoria dos três eadem (mesmas partes, mesma causa de pedir, mesmo pedido), conquanto muito prestigiosa e realmente útil, não é suficiente em si mesma para delimitar com precisão o âmbito de incidência do impedimento causado pela litispendência. Considerando o objetivo do instituto (evitar o bis in idem), o que importa é evitar dois processos instaurados com o fim de produzir o mesmo resultado prático (DINAMARCO, Cândido Rangel. Instituições de Direito Processual Civil. 4 ed., rev., atual., e com remissões ao Código Civil de 2002. São Paulo: Malheiros, pp. 62-63).

79. "A teoria dos três eadem na caracterização da litispendência/coisa julgada deve transcender a identidade dos elementos da ação para entender que o impedimento se destina a evitar processos que tenham o mesmo resultado prático" (AgRg no AREsp 188.343/SC, Rel. Ministro Herman Benjamin, 2a t, 11/09/2012).

80. GIDI, Antonio. Coisa julgada e litispendência em ações coletivas. São Paulo: Saraiva, 1995, p. 219. Também assim para o STJ (AGRMC - 14216. STJ, rel. Min. Napoleão Nunes Maia Filho. $3^{\text {a }}$ seção, 23/10/2008)

81. GRINOVER, Ada Pellegrini. Uma nova modalidade de legitimação à ação popular. Possibilidade de conexão, continência e litispendência. In: MILARÉ, Édis (coord.). Ação Civil Pública. São Paulo: RT, 1995, p. 24-25.

82." A nosso ver, nas Ações Coletivas estará sempre uma legitimação processual coletiva que é, justamente, a possibilidade de almejar a proteção dos direitos coletivos lato sensu (difuso, coletivo e individuais homogêneos), ainda que haja coincidência entre os interesses próprios de quem atua com os daqueles que serão, em tese, beneficiados com a decisão a ser prolatada" (GOMES JR. Luiz Manoel. Curso de Direito Processual Coletivo. 2 ed. São Paulo: SRS Editora, 2008, p. 85).

83. A construção, citando Pontes de Miranda, é de SOARES, Felipe Lopes. Litispendência entre ação civil pública e ação popular. Revista de Processo. v. 171, ano 34. São Paulo: Editora RT, mai. 2009, p. 151. É a orientação da jurisprudência: "Para fins de configuração de continência entre ações coletivas, a identidade de partes deve ser interpretada sob a ótica dos beneficiários atingidos pelos efeitos da decisão, de modo que, ainda que não sejam necessariamente as mesmas partes "físicas", se as partes "juridicas" são as mesmas, impõe-se seja reconhecida a continência" (TRF-4 - AC: 50098615920134047100 RS 5009861-59.2013.404.7100, Rel.: Candido Alfredo Silva Leal Junior, $4^{a}$ t., 21/05/2014). 
tutos processuais coletivos (candidatos, partidos e o Ministério Público, em legitimidade ativa concorrente e disjuntiva). ${ }^{84}$

Com o novo art.96-B, nenhuma dúvida que a litispendência e a continência devem ser reconhecidas independentemente dos substitutos processuais coletivos. A controvérsia está em definir a consequência do reconhecimento da litispendência e da continência entre demandas eleitorais.

\subsection{Consequência do reconhecimento da litispendência e da continência nas ações eleitorais}

A litispendência é um requisito processual negativo para o julgamento de mérito (art. 267, V, CPC; art. 485, V, NCPC) ${ }^{85}$ Assim, flagrada a litispendência, a partir dos critérios indicados no tópico anterior, a segunda demanda idêntica-repetida deve ser extinta.

A continência - litispendência parcial - enseja a mesma consequência, mas apenas em relação à zona de interseç̧ão quando a continente precede a contida. A extinção da contida proposta depois da continente já era defendida por parcela relevante da doutrina e está em alguns precedentes. ${ }^{86}$ Agora é como está no art. 57 do NCPC: na hipótese de continência, se a continente (mais ampla) já estiver tramitando quando for proposta a contida, a segunda (menos ampla) deverá ser extinta sem julgamento de mérito. ${ }^{87} \mathrm{~A}$ simples reunião (por conexão) só se verifica se

84. ALMEIDA, Gregório Assagra de. Direito Processual Coletivo Brasileiro - um novo ramo do direito processual. São Paulo: Saraiva, 2003, p. 134.

85."Diz-se que a litispendência de um primeiro processo é um pressuposto negativo para um segundo, com conteúdo idêntico, porque o segundo, mesmo preenchendo todas as condiçōes de prosperar, em virtude de um elemento que the é extrínseco, isto é, pelo mero fato da existência de um primeiro processo igual, será trancado. Então, a litispendência anterior é um pressuposto processual negativo, impedindo a validade de uma segunda relação jurídica processual idêntica" (ALVIM, Arruda. Manual de Direito Processual Civil. Vol. 1: Parte Geral, 7 ed. rev. atual. e ampl. São Paulo: Editora Revista dos Tribunais, p. 523).

86. "Se a causa continente (a maior) for proposta antes da menor, não há que se falar em junção, pois sendo ajuizada a causa contida (a menor), sucessivamente à causa continente (a maior), segue-se que toda causa menor já está pendente na anterior, desde que haja identidade 'integral', entre a menor e a parte da maior que the corresponde. Se assim é, o tratamento jurídico a ser emprestado à hipótese não será o de junção, mas sim o de argüir objeção de litispendência e o de, conseqüentemente, extinguir-se a segunda ação sem julgamento de mérito" (ALVIM, A. Manual de direito processual civil. 5. ed. São Paulo: RT, 1996. V.1, p. 307). No mesmo sentido: "A continência encerra, na verdade, litispendência parcial, já que haverá identidade parcial entre os pedidos formulados nos dois processos. Quando os pedidos realizados no segundo processo são menos abrangentes, haverá simplesmente litispendência, devendo este processo ser extinto sem julgamento do mérito" (ALVIM WAMBIER, Teresa Arruda. Litispendência em ações coletivas. In LUCON, Paulo Henrique dos Santos (Coordenador). Tutela coletiva: 20 anos da Lei da Ação Civil Pública e do Fundo de Defesa de Direitos Difusos, 15 anos do Código de Defesa do Consumidor. São Paulo: Atlas, 2006, p. 264). Ainda: MEDINA, José Miguel Garcia; WAMBIER, Teresa Arruda Alvim. Parte geral e processo de conhecimento. São Paulo: RT, 2009. pp. 105, 110-111. No STJ a orientação estava para determinara a reunião de processos (EDcl no REsp 1394617/SC, Rel. Min. Ari Pargendler, $1^{\text {a }}$ t., 20/05/2014). Mas havia julgados reconhecendo a necessidade de extinção. Entre outros: "Se a causa continente (a maior) for proposta antes da ação com pedido menor, tem-se que o pedido menor já está contido no primeiro pedido maior. A solução jurídica no caso é a extinção do segundo processo em razão da litispendência “ (TRF1, AC 1999.36.00.008262-0/MT, Rel. Des. Federal Selene Maria De Almeida, 5a t., 22/05/2009).

87. Conferir OLIVEIRA, Bruno Silveira de. In: DIDIER JR., Fredie, in WAMBIER, Teresa Arruda Alvim; DIDIER JR., Fredie; TALAMINI, Eduardo, DANTAS, Bruno. Breves Comentários ao novo Código de Processo Civil. São Paulo: RT, 2015, pp. 226-227. 
a cronologia foi inversa (contida proposta antes da continente).$^{88}$

Nas ações eleitorais a consequência da extinção merece outra análise; uma análise, aqui também, conectada com o microssistema dos processos coletivos, a considerar a legitimidade extraordinária. ${ }^{89}$

É neste sentido que o $\$ 1^{\circ}$ do art. 96-B fixa que o "ajuizamento de ação eleitoral por candidato ou partido político não impede ação do Ministério Público no mesmo sentido". O novo dispositivo da Lei Eleitoral quer evitar o reconhecimento de litispendência impeça o Ministério Público de intentar ação idêntica - o que é correto à luz do microssistema dos processos coletivos. Basta imaginar a hipótese de extinção de uma AIJE proposta pelo Ministério Público repleta de provas colhidas em procedimento administrativo em razão de uma demanda proposta alguns dias antes por um Partido Político com escasso material probatório. ${ }^{90}$

O problema é que a contrario sensu o dispositivo está a dizer que o ajuizamento por um determinado partido político impede o ajuizamento por outro partido (ou candidato) da mesma ação (ou de uma contida). E a regra extraída da leitura a contrario sensu está em dissonância com a melhor leitura do microssistema dos processos coletivos. E, sobretudo, com a leitura que o microssistema merece no ambiente do Direito Eleitoral.

Para as ações coletivas - e agora também para as ações eleitorais - a litispendência e a continência não devem apontar para a extinção, mas apenas para a reunião dos processos. ${ }^{91}$ Idêntica orientação deve pautar as ações eleitorais, incompatíveis que são - tais quais as ações coletivas - com a "aplicabilidade fria e rígida" da extinção. ${ }^{92}$

$\mathrm{O}$ art. $5^{\circ}, \S 3^{\circ}$, da Lei da Ação Popular - que manda reunir; não extinguir - deve ser subsidiariamente aplicado para enriquecer o $₫ 1^{\circ}$ do art. 96-B da Lei Eleitoral. Isso porque a "extinção pura e simples com base da litispendência" ou da continência de uma ação eleitoral "poderá causar risco à efetiva tutela jurisdicional" da lisura das eleiçôes. ${ }^{93} \mathrm{E}$ este risco não está apenas para os casos de posterior propositura pelo Ministério Público.

88."(...) a continência costuma ser apontada como uma litispendência parcial. Em parte a demanda de maior extensão coincide com a demanda menos ampla, e na parte que a excede ela é somente conexa a esta" (DINAMARCO, Cândido Rangel. Fundamentos do Processo Civil Moderno. 6ª ed. Tomo I. São Paulo: Malheiros, 2010, p. 710).

89. Apontando para a solução da reunião nos casos de duplicidade de lides coletivas, RODRIGUES, Marcelo Abelha. Ação Civil Pública. In Procedimentos Especiais Cíveis. FARIAS, Cristiano Chaves de. DIDIER JUNIOR, Fredie (coords.). São Paulo: Saraiva, 2003, pp.385-386.

90. O exemplo, aqui adaptado para o Direito eleitoral, é de ALMEIDA, Gregório Assagra de. Direito Processual Coletivo Brasileiro - um novo ramo do direito processual. São Paulo: Saraiva, 2003, pp. 360-361.

91. Correndo o risco de dizer o óbvio, é claro que esta assertiva pressupóe diferentes legitimados extraordinários nas ações coletivas. Se um mesmo partido propõe duas ações idênticas, a segunda merece extinção por litispendência.

92. ALMEIDA, Gregório Assagra de. Direito Processual Coletivo Brasileiro - um novo ramo do direito processual. São Paulo: Saraiva, 2003, pp. 360-361. Há julgados nos dois sentidos. Pela reunião: TJ-MG AI: 10024120921705001 MG , Rel.: Cabral da Silva, 10ª Câmara Cível, 02/04/2014. Contra a reunião (pela extinção): TRF-2 - AG: 201202010165317 , Rel.: Des. Federal Aluisio Gonçalves de Castro Mendes, $5^{\mathrm{a}}$ t., 24/05/2013.

93. Os trechos destacados foram extraídos da doutrina de ALMEIDA, Gregório Assagra de. Direito Processual Coletivo Brasileiro - um novo ramo do direito processual. São Paulo: Saraiva, 2003, pp. 360-361. 
Não é, por tais razões, apenas o Ministério Público que pode propor ação eleitoral no mesmo sentido de ação anteriormente proposta por candidato ou partido político, como está no $\S 1^{\circ}$ do art. 96-B. Todos os litisconsortes facultativos podem propor ações em litispendência ou continência. A consequência é a reunião dos processos. ${ }^{94}$

Esta é melhor opção para o Direito Eleitoral. Evita-se um possível conluio entre candidatos e partidos. Uma determinada AIJE (mal formulada; mal instruída) pode ser proposta sob encomenda apenas vetar a propositura de outra $\mathrm{AIJE}{ }^{95} \mathrm{~A}$ regra é que não haja prejuízo na reunião.

Em verdade, nos caso de continência e litispendência, o que ocorre é uma fusão das demandas. ${ }^{96} \mathrm{E}$ a fusão transforma as partes das ações originais em litisconsortes da demanda única. $\mathrm{E}$ simplesmente porque se trata de litisconsórcio facultativo unitário, a exigir soluções convergentes. Se os autores poderiam ser litisconsortes desde a propositura, podem ser também na reunião dos processos. ${ }^{97}$ Aliás, é o que está expresso no $§ 2^{\circ}$ do art. $96-\mathrm{B}$, mencionado para os casos de conexão.

\subsection{Exceções à regra de reuniáo das demandas eleitorais propostas em litispendência ou continência}

A conveniência da reunião, no entanto, pressupóe atenção aos princípios da efetividade, especialmente, da celeridade (tópico 3.1). Como nos casos de conexão, a reunião é inviável se tiver havido o julgamento de uma ação eleitoral. Para estes casos o STJ aponta a extinção da ação idêntica posteriormente proposta. ${ }^{98}$ No caso de continência, impóe-se aqui (se a contida vier depois da continente) a aplicação da extinção parcial, como agora está no art. 57 do NCPC. ${ }^{99}$ Se a continente vier depois de já julgada a contida, não cabe reunião. ${ }^{100}$

Depois, se esta ação anterior (idêntica ou contida) for julgada procedente ou improcedente com trânsito em julgado, o interesse coletivo, reconhece-se, foi eficientemente tutelado. Caso a improcedência seja por insuficiência de prova, autoriza-se, por qualquer dos legitimados, a repropositura a partir de outras ou novas provas (art. 96-B, $\S 3^{\circ}$ - coisa julgada secundum eventum probationis - tópico 06).

94." quando ocorre litispendência com partes diversas, a solução não pode ser a extinção de um dos processos, mas a reunião deles para processamento simultâneo. É que de nada adiantaria extinguir um dos processos, pois a parte autora, como co-legitimada, poderia intervir no processo supérstite, na qualidade de assistente litisconsorcial. Por uma medida de economia, se isso for possivel (se houver compatibilidade do procedimento e respeito às regras de competência absoluta), os feitos devem ser reunidos" (DIDIER JÚNIOR, Fredie; ZANETI JÚNIOR, Hermes, Curso de direito processual civil, v. 4, 2. ed. Salvador: JusPodivm, 2009, p. p. 163)

95. Conferir GIDI, Antônio. Coisa julgada e litispendência em ações coletivas` São Paulo: Saraiva, 1995, pp. 133-134.

96. OLIVEIRA, Bruno Silveira de. In DIDIER JR., Fredie, in WAMBIER, Teresa Arruda Alvim; DIDIER JR., Fredie; TALAMINI, Eduardo, DANTAS, Bruno. Breves Comentários ao novo Código de Processo Civil. São Paulo: RT, 2015, p. 226.

97. GRINOVER, Ada Pellegrini. Coisa Julgada erga omnes, secundum eventum litis e secundum probationem. Revista de Processo. v. 126, ano 30. São Paulo: Editora RT, ago. 2005, p. 17.

98. RMS: 24196 ES 2006/0101994-6, Rel.: Min. Felix Fischer, 5a t., 18/02/2008.

99. Já era assim que o STJ tratava a hipótese (REsp 953.034/PR, Rel. Ministro Luiz Fux, Primeira Turma, 29/06/2009).

100. "Não há reunião de ações em virtude da ocorrência de continência se um dos processos já tiver sido julgado" (3a T., Agravo no AREsp no 422.477/MG, Rel. Min. Ricardo Villas Bôas Cueva, DJe de 30/10/2014). 
Uma hipótese intermediária é a propositura de uma ação idêntica ou contida quando já tiver sido julgada a anterior - e este julgamento tiver sido de improcedência por falta de prova, mas ainda sem trânsito em julgado. Aqui os princípios da efetividade e da celeridade devem conformar uma orientação que autorize a propositura/tramitação das ações eleitorais posteriores. Neste caso é necessária a cronológica da solução do art. 96-C, evitando que a nova ação aguarde o trânsito em julgado da anterior. Para tal a nova demanda, para não merecer extinção, deverá estar aparelhada com outras ou novas provas em relação à anterior - o que deverá ser demonstrado pelo autor para um juízo de admissibilidade (tópico 6.1). Se a coisa julgada não se forma quando o pedido é julgado improcedente por ausência de prova, é possível dizer que a litispendência também não se revela neste caso.

Também aqui a alternativa alvitrada por parcela da doutrina é uma suspensão do processo prejudicialidade (art. 265, IV, CPC; $313, \mathrm{~V}, \mathrm{NCPC}) .{ }^{101} \mathrm{~A}$ suspensão por prejudicialidade - tal como a espera pelo trânsito em julgado - viola o princípio da celeridade, tão caro ao Direito Eleitoral. ${ }^{102}$ Importante reiterar aqui que os processos de cassação de mandato devem estar julgados, em todas as instâncias, no máximo em um ano. ${ }^{103} \mathrm{~A}$ solução deve passar por esta referência de duração razoável do processo no Direito Eleitoral.

Outra hipótese em que a reunião é desaconselhada está para os casos de continência em que a demanda contida tenha instrução concluída ou avançada. Não é possível paralisar uma ação eleitoral de cassação pronta para julgamento para reunir com a continente que demanda prova na parcela não coincidente. Aqui, se a contida estiver avançada, a instrução produzida pode ser aproveita pela continente, sem reunião. ${ }^{104}$

Por fim, pelas razões já mencionadas ao tratar de conexão, impossível cogitar a aplicação do art. $96-\mathrm{B}, \S 2^{\circ}$, reunindo processos em instâncias diferentes (conferir tópico 3.1).

\section{5+3. A continência não subverte a regra da reunião pela prevenção}

Define o art. 96-B que serão reunidas para julgamento comum as ações eleitorais propostas por partes diversas sobre o mesmo fato. Os mesmos fatos podem ensejar o reconhecimento de identidade em diferentes níveis: conexão ou continência. A competência para julgar os processos reunidos, como também está no art. 96-B, se dá no Juiz que tiver “recebido a primeira [demanda sobre os mesmos fatos]". A regra de prevenção da Lei Eleitoral não distingue conexão de continência.

101. DIDIER JR., Fredie; ZANETI JR., Hermes. Curso de direito processual civil: Processo coletivo. $4^{\mathrm{a}}$ Ed. Vol. 4. Salvador: Editora PODIVM, 2009, p. 175.

102. JARDIM, Torquato. Direito Eleitoral Positivo. 2. ed. Brasília: Brasília Jurídica, 1998, p. 151.

103. Lei 9.504/97."Art. 97-A. Nos termos do inciso LXXVIII do art. 50 da Constituição Federal, considera-se duração razoável do processo que possa resultar em perda de mandato eletivo o periodo máximo de 1 (um) ano, contado da sua apresentação à Justiça Eleitoral. $\leqslant$ 1o A duração do processo de que trata o caput abrange a tramitação em todas as instâncias da Justiça Eleitoral".

104. OLIVEIRA, Bruno Silveira de. In DIDIER JR., Fredie, in WAMBIER, Teresa Arruda Alvim; DIDIER JR., Fredie; TALAMINI, Eduardo, DANTAS, Bruno. Breves Comentários ao novo Código de Processo Civil, São Paulo: RT, 2015, p. 227. 
O STJ tem decisões definindo que a prevenção é instrumento apto para modificar a competência apenas em caso de conexão - e não de continência. ${ }^{105} \mathrm{O}$ tema é controvertido em jurisprudência. ${ }^{106}$ PONTES DE MIRANDA, citado no acórdão do STJ, sustenta que o art. 106 do CPC (que trata da prevenção) refere-se apenas a conexão (e não a continência). Para BARBOSA MOREIRA a "continência está contida na conexão" 107 Sendo assim, o art. 106 abrangeria casos de conexão e continência - contrariando a orientação predominante $e$ determinando, sempre, a reunião no juízo prevento. ${ }^{108}$

Agora o art. 58 do NCPC, responsável por tratar da prevenção, não faz distinção entre conexão e continência - o que levou a doutrina a concluir pela submissão da continência à regra de prevenção. ${ }^{109} \mathrm{Da}$ mesma forma o art. $96-\mathrm{B}$ não se refere especificamente a conexão; trata de ações sobre o mesmo fato - a englobar conexão e continência (os dois institutos pressupõem a coincidência em torno dos fatos, é claro). Portanto, a continência no Direito Eleitoral - nos casos em que provoca fixação/modificação de competência - orienta-se, tal qual a conexão, pela prevenção.

Estas consideraçóes, no entanto, devem ser lidas em consonância com as demais regras abordadas neste texto (conferir tópicos 5.1, 5.2 e 5.3).

105. "Se reconhecida a continência entre as ações, realmente não se pode adotar o critério da prevenção para determinar a reunião dos processos. O juizo em que tramite a causa continente é que deverá julgar a causa contida” (STJ, Relator: Ministra Nancy Andrighi, $3^{a}$ t., 27/09/2011). Ainda há ampla controvérsia na jurisprudência.

106. Em sentido contrário à posição do STJ, entre outros: "No caso, o instituto da continência desloca a competência por prevenção ao Juizo que exarou o primeiro despacho. Inteligência dos artigos 104, 105 e 106 do CPC" (Conflito de Competência No 70050479252, Terceira Câmara Cível, Tribunal de Justiça do RS, Rel. Eduardo Delgado, Julgado em 29/05/2014).

107. Sobre a continência estar contida na conexão, conferir a explicação de BARBOSA MOREIRA, José Carlos. A conexão de causas como pressuposto da reconvenção. São Paulo: Saraiva, 1979, p. 133.

108. Assim também para parcela da doutrina: "No cenário inverso, isto é, proposta em um segundo momento a demanda mais extensa, deverá esta ser reunida à menos extensa, perante o juizo prevento" (OLIVEIRA, Bruno Silveira de. In.: WAMBIER, Teresa Arruda Alvim e outros (cood.). Breves comentários ao novo código de processo civil. São Paulo: RT, 2015.p. 226). NO mesmo sentido:"A noção de prevenção ganha importância quando se está diante de ações que devem ser reunidas. Essas ações são as conexas, as continentes e aquelas entre as quais existe a relação de acessoriedade" (WAMBIER, Luiz Rodrigues e outros. Curso avançado de processo civil, volume 1: teoria geral do processo de conhecimento. 7 ed. rev. e atual. São Paulo: RT, 2005. pp.101-102)

109. Quem já comentou o novo dispositivo defende que agora há uma indistinção de tratamento que submente a continência ao critério de prevenção: "O art. 58 do CPC/2015 não limita o seu comando aos casos de ações conexas. Seu caráter genérico e sua própria posição no texto do Código evidenciam que, também quando se tratar de reunir açôes entre as quais haja relação de continência ou prejudicialidade, aplicar-se-á o critério da prevenção - observado o disposto no art. 54" (WLADECK, Felipe Scripes. Código de Processo Civil Anotado. CRUZ e TUCCI, José Rogério; FERREIRA FILHO, Manoel Caetano; APRIGLIANO, Ricardo de Carvalho; DOTTI, Rogéria Fagundes; MARTINS, Sandro Gilbert (Coords.). AASP-OAB/PR, 2015, p. 100). 


\section{A coisa julgada secundum eventum probationis (segundo o resultado da prova) no Direito Eleitoral}

A regra geral da coisa julgada material determina que flagrada a identidade de ações, a demanda proposta em momento seguinte mereça extinção (art. 267, V, CPC; art. 485, V, NCPC). Trata-se de garantia constitucional (art. $\left.5^{\circ}, \mathrm{XXXVI}, \mathrm{CF}\right){ }^{110} \mathrm{~A}$ ofensa à coisa julgada, inclusive, é hipótese de rescindibilidade do julgado (art.485, IV, CPC; art.966, IV) ou até mesmo, valendo-se da designação latina, querela nullitatis. ${ }^{111}$ Também como regra, a ação julgada improcedente, ainda que por insuficiência de prova, é decisão de mérito e produz coisa julgada material. ${ }^{112}$

Agora o $\S 3^{\circ}$ do art. 96-B estipula que ao articular uma solução jurídica típica de açóes coletivas: a coisa julgada secundum eventum probationis. Julgada improcedente uma ação de cassação de mandato (ou outra ação eleitoral que trata de direitos transindividuais) por insuficiência de provas, outra idêntica pode ser apresentada, desde que a partir de outras ou novas provas.

Antes de tratar da coisa julgada secundum eventum probationis, é importante relembrar que o TSE sempre entendeu que, os mesmos fatos, julgados em AIJE, AIME ou RCED, não autorizavam exceção de coisa julgada - a partir dos mesmos argumentos já mencionados. Abstratamente consideradas, as ações teriam causas de pedir próprias e consequências jurídicas distintas. ${ }^{113}$ Agora o $\S 3^{\circ}$ do art. 96-B explicita que a coisa julgada impede a análise de ação posterior. Se a ação coletiva-eleitoral anterior, proposta por qualquer dos legitimados, tiver apreciado o mesmo fato, o conhecimento da subsequente está vedado. Não importa que a mesma situação jurídico-substancial tenha sido incialmente veiculado em uma AIJE e depois em uma AIME.

Parece óbvio, mas é uma correção importante na orientação jurisprudencial que prevalecia até aqui. A coisa julgada formada em demanda sobre os mesmos fatos induz à extinção

110. MARINONI, Luiz Guilherme MARINONI:" a coisa julgada material é atributo indispensável ao Estado Democrático de Direito e à efetividade do direito fundamental de acesso ao Poder Judiciário" (MARINONI, Luiz Guilherme. O princípio da segurança jurídica dos atos jurisdicionais - a questão da relativização da coisa julgada material. In DIDIER JUNIOR, Fredie (org.), Relativização da coisa julgada: Enfoque Crítico, Salvador: JusPODIVM, 2004, p. 162).

111. Sobre as consequências da ofensa à coisa julgada, nos diferentes momentos em que é flagrada, WAMBIER, Teresa Arruda Alvim. Nulidades no processo e da sentença. São Paulo: RT, 7a ed., 214, pp. 382-386.

112. "Dúvida não há, portanto, de que a insuficiência ou falta de provas acarreta a improcedência do pedido, não a extinção do processo sem julgamento do mérito. Se o autor não consegue provar o fato constitutivo de seu direito, deverá sofrer as consequências da ausência ou insuficiência de provas, que invariavelmente será a improcedência de seu pedido, nos termos do art. 269, I, CPC. Em outras palavras, não provado o direito postulado, o julgador deve negar a pretensão, que ocorrerá com o julgamento de mérito do pedido" (REsp 873.884/SP, Rel. Min. ARNALDO ESTEVES LIMA, 5ª t., 29/03/2010). Há quem faça, registre-se, uma leitura crítica do reconhecimento de julgamento de mérito em caso de insuficiência de provas, admitindo a repropositura mesmo em ações individuais (RODRIGUES, Daniel Colnago; SOUZA, Gelson Amaro de. Ausência de provas e falsa improcedência no processo civil brasileiro. In: Improcedência. MOUZALAS, Rinaldo; SILVA, Beclaute Oliveira; MARINHO, Rodrigo Saraiva (coords.). Salvador: PODIVM, 2015, pp. 299-313).

113."O recurso contra expedição de diploma (RCED), a Ação de Investigação Judicial Eleitoral (AIJE) e a Ação de Impugnação de Mandato Eletivo (AIME) possuem causas de pedir própria e consequência jurídica distinta. Assim, o julgamento favorável ou desfavorável de cada uma dessas ações não influencia no trâmite uma das outras" (AREspe 26.276/CE, Rel. Min. Marcelo Ribeiro, DJ de 7.8.2008; REspe 28.015/RJ, Rel. Min. José Delgado, DJ de 30.4.2008). 
da demanda subsequente. Independentemente da discrepância no polo ativo (reconhecendo, mais uma vez, a legitimação extraordinária nas ações eleitorais). Trata-se de importante instrumento de aperfeiçoamento da garantia da segurança jurídica no Direito Eleitoral. ${ }^{114}$

A coisa julgada nas ações eleitorais é agora erga omnes, própria das ações coletivas. Há uma ampliação dos limites subjetivos. Não apenas quem foi parte é atingido, mas toda a coletividade - precisamente em atenção à transindividualidade. Esta transindividualidade da tutela da lisura do processo eleitoral é o vetor de ampliação dos limites subjetivos da coisa julgada. Determinada a cassação de um mandato e a consequente realização de novas eleições, todos os titulares deste direito difuso à lisura das eleições estão tutelados. ${ }^{115}$

E a coisa julgada opera nos dois sentidos. Eventual decisão de improcedência com trânsito em julgado imuniza a situação jurídico-substancial. A imutabilidade própria da coisa julgada impede novas investidas dos legitimados ativos para estas ações de cassação. A coisa julgada nas ações eleitorais atua, enfim, pro et contra. Admitir uma série de ações eleitorais idênticas, depois de uma decisão definitiva sobre os fatos, violaria a percepção de segurança jurídica tão importante para disputa eleitoral. Inadmissível a contraposição de coisas julgadas conflitantes. ${ }^{116}$

A exceção está para os casos de improcedência por insuficiência de provas. Aqui entra e cena o instituto da coisa julgada secundum eventum probationis - adotada expressamente pelo novo $₫ 3^{\circ}$ do art. $96-\mathrm{B}$ da Lei Eleitoral.

A técnica da coisa julgada secundum eventum probationis é utilizada para duas situaçóes jurídica. Primeiro para os casos de procedimentos que limitam a cognição (e por isso autorizam nova discussão em cognição exauriente). Segundo para os casos nos quais o sistema não se conforma com a coisa julgada a partir de uma improcedência por insuficiência de provas, em razão dos direitos indisponíveis envolvidos. ${ }^{117}$ Por opção do legislador, a coisa julgada não se forma quando o pedido é julgado improcedente por ausência de prova. ${ }^{118}$ É o caso das ações coletivas. Adota-se a primazia da tutela de mérito. Por idêntico pressuposto, é também o caso das ações eleitorais.

A partir da mudança, se a ação de cassação for julgada procedente ou improcedente, a imutabilidade é "consequência natural da transindividualidade". ${ }^{119}$ No entanto, se a improcedência se der por insuficiência de prova, é possível a propositura de nova e idêntica ação - com outras ou novas provas. A solução é análoga à adotada na ação popular (art. 18),

114. TALAMINI, Eduardo. Coisa julgada e sua Revisão. São Paulo: RT, 2005, pp. 50-51.

115. É verdade que esta questão já poderia ser resolvida, para os casos de procedência das ações de cassação, em carência de ação por falta de interesse de agir. Não haveria interesse de agir em propor uma ação de cassação contra um candidato já cassado. Mas a questão deve ser avaliada à luz da coisa julgada nos casos de improcedência, com a imunização do candidato em relação a novas ações sobre os mesmos fatos - à exceção da insuficiência de provas.

116. BARBOSA MOREIRA, José Carlos. A Ação Popular do Direito Brasileiro como Instrumento de Tutela Jurisdicional dos Chamados 'Interesses Difusos'. Em: Temas de Direito Processual. São Paulo: Saraiva, 1977, p. 122.

117. WATANABE, Kazuo. Da cognição no processo civil. São Paulo: RT, 1987, pp. 89-90.

118. ALMEIDA, Gregório Assagra de. Direito processual coletivo brasileiro: Um novo ramo do direito processual. São Paulo: Saraiva, 2003, p. 352

119. ZAVASCKI, Teori Albino. Processo Coletivo, $2^{\text {a }}$ ed. São Paulo: RT, 2007, p. 80 
na ação civil pública (art. 16) e também no Anteprojeto de Código Brasileiro de Processos Coletivos (art. 13) ${ }^{120}$ A construção jurídica que ampara as hipóteses é a mesma: primazia da tutela de mérito diante da relevância dos direitos envolvidos.

Não interessa à tutela da lisura do processo eleitoral que eventual quebra do princípio da autenticidade eleitoral torne-se inquestionável (imutável) a partir de uma decisão sem julgamento de mérito por insuficiência de provas. Até porque "a qualidade da democracia representativa está relacionada com a normalidade e lisura das eleiçôes". ${ }^{121}$ Assim sendo, se um legitimado para uma ação eleitoral não se desincumbiu adequadamente do ônus da prova, a improcedência não forma coisa julgada. Interessa à tutela da lisura oferecer outra chance a quem dispuser de novas ou outras provas.

Como os mesmos argumentos já apresentados ao tratar da necessidade de reunião de processos em continência e litispendência (tópico 5.1), a solução evita eventual conluio entre candidatos próximos, falsos adversários (não raro, infelizmente). Impede-se que a intencional propositura de uma demanda eleitoral mal concebida, com prova escondida, apenas para formar uma coisa julgada a partir da improcedência. ${ }^{122} \mathrm{O}$ objetivo de imunizar o candidato que violou a lisura do processo eleitoral está vedado com a adoção da coisa julgada secundum eventum probationis pela legislação eleitoral.

Os Regionais Eleitorais, antes do novo art. 96-B, negavam a aplicação da coisa julgada secundum eventum probationis. ${ }^{123}$ Apesar desta orientação, ao mesmo tempo o TSE ressalvava que "se não forem produzidas novas provas (...), não há como se distanciar das conclusões proferidas nos julgados anteriores". ${ }^{124}$ Havia uma construção jurisprudencial que flertava com o instituto. Agora o $\$ 3^{\circ}$ do art. 96-B consolida a coisa julgada secundum eventum probationis para as ações eleitorais.

\subsection{O que se entende por outras ou novas provas que autorizam a propositura de ação proposta sobre o mesmo fato. Juízo de admissibilidade}

A repropositura pressupõe improcedência anterior por insuficiência de prova. Não importa propriamente a escassez de provas. Podem ser muitas as provas, mas insuficientes para a formação do juízo de mérito. ${ }^{125}$

120. Conferir, entre outros, DECOMAIN, Pedro Roberto. Conexão entre Ações Populares e entre Ação

Popular e ações Coletivas correlatas. Revista Dialética de Direito Processual n 71, pp. 112-115.

121. Salgado, Eneida Desiree, Princípios Constitucionais Eleitorais, São Paulo: Editora Forum, 2010, p. 54.

122. Conferir GIDI, Antônio. Coisa julgada e litispendência em ações coletivas. São Paulo: Saraiva, 1995, pp. 133-134.

123."O ordenamento jurídico vigente veda, em regra, a formação da coisa julgada secundum eventum probationis. Com isso, o exaurimento ou não das vias probatórias é irrelevante para que se opere a estabilização dos efeitos de decisão de mérito contra qual não caiba mais recurso" (TRE-BA. RE n²9582, Rel. CARLOS D'ÁVILA TEIXEIRA, 27/1/2015).

124. TSE, Recurso Ordinário n. ${ }^{\circ}$ 2.233/RR, Relator: Ministro FERNANDO GONÇALVES, DJE $10 / 3 / 2010$

125. RODRIGUES, Marcelo Abelha. Ação civil pública e meio ambiente, 2. ed., Rio de Janeiro: Forense, 2004, p. 246. 
$\mathrm{O} \S 3^{\circ}$ do art. 96-B subordina o conhecimento de nova ação à apresentação de outras ou novas provas. A conjunção "ou" sugere alternativa: outras ou novas. Não há sentido. Se as provas forem outras, serão novas. As provas são outras em relação àquelas produzidas no processo anterior (julgado improcedente por insuficiência de prova). Se outras, também novas (inéditas) em relação àquelas, por óbvio.

Outras ou novas não querem dizer supervenientes. É dizer: as provas podem ser pré-existentes ou contemporâneas à instrução do processo julgado improcedente por insuficiência de prova. Se estas provas não tiverem sido apresentadas, serão novas para fins de admissibilidade do processo subsequente. ${ }^{126}$

A apresentação de novas provas é uma condição para o conhecimento da ação repetida. Há, portanto, um juízo prévio de admissibilidade. Esta admissibilidade da ação reproposta está condicionada a uma análise in limine litis que aponte para a possibilidade de superação da insuficiência a partir das novas provas apresentadas. É claro que a suficiência só será aferida mesmo ao momento do julgamento de mérito, com o final da instrução. Entretanto, as novas provas apresentadas devem autorizar uma perspectiva de superação da insuficiência. Esta é a condição de admissibilidade, sem a qual a coisa julgada se apresentada como um requisito processual negativo (art. 267, V, CPC; art. 485, V, NCPC).

\section{Conclusões}

O art. 96-B adota técnicas próprias do microssistema dos processos coletivos. Além da inclusão de dispositivos específicos, atrai a aplicação subsidiária da lógica jurídica das ações coletivas para açôes eleitorais que digam com os direitos transindividuais. A partir daí é possível extrair as seguintes conclusóes:

i) Não obstante alguns avanços nos últimos anos, ainda há um indesejável espaço de sobreposição de ações que, a partir de causas de pedir coincidentes, podem conduzir à inelegibilidade/cassação.

ii) O tema da conexão, continência, litispendência e coisa julgada, à exceção de alguns poucos e recentes julgados, sempre mereceu um tratamento inadequado da jurisprudência eleitoral. As ações eleitorais típicas eram abstratamente cotejadas para apontar, em tese, a inexistência de conexão, assim como continência, litispendência e coisa julgada.

iii) $\mathrm{O}$ art. $96-\mathrm{B}$ (e $\$ \$ 1^{\circ}, 2^{\circ}$ e $\left.3^{\circ}\right)$ é instrumento apto alterar a jurisprudência eleitoral em relação aos casos de conexão, continência, litispendência e coisa julgada. Agora para flagrar pontos de contato entre açóes eleitorais é necessário adotar o critério casuístico, avaliando concretamente as ações eleitorais típicas para aferir, por exemplo, conexidade.

126. NEVES, Daniel Amorim Assumpção. Manual de Direito Processual Civil, $6^{a}$ ed. São Paulo: Saraiva, 2013, p. 557. 
iv) A nova regra determina de forma expressa que as ações eleitorais sejam reunidas a partir do critério da prevenção.

v) Não é possível reunir ações eleitorais conexas se uma delas já tiver sido julgada ou estiver em fase avançada de instrução. A regra de reunião para julgamento simultâneo deve ser ponderada a partir do princípio da efetividade e da celeridade no Direito Eleitoral.

vi) A competência absoluta do Corregedor para julgamento de AIJE's (de constitucionalidade duvidosa) não pode ser instrumento de burla ao princípio do juiz natural.

vii) O status constitucional da AIME não é motivo para derrogação da regra de prevenção. Havendo conexão, a AIME deve ser reunida ao processo antes distribuído.

viii) As ações eleitorais estão submetidas às regras do microssistema de processos coletivos que não colidam com regras próprias do Direito Eleitoral.

ix) A continência, a litispendência e a coisa julgada são aferidas independentemente de quem figura no polo ativo, pois a legitimidade nas ações eleitorais é sempre extraordinária.

x) O reconhecimento da litispendência não induz à extinção, mas à reunião dos processos idênticos. Mesma conclusão em relação à continência, nos casos de a ação contida ter sido proposta depois da continente.

xi) As exceçôes à reunião de processos em litispendência e continência verificam-se em atenção aos princípios da efetividade e da celeridade.

xii) A continência não subverte a regra da reunião dos processos pela prevenção. Proposta depois a continente, a reunião se dá na contida distribuída antes - no juízo prevento.

xiii) $\mathrm{O} \S 3^{\circ}$ do art. 96-B adota para as ações eleitorais o instituto da coisa julgada secundum eventum probationis, típico das ações coletivas. A improcedência por insuficiência de provas pode ser corrigida por ação idêntica, com novas provas.

xiv) As novas provas não devem ser necessariamente supervenientes. Basta que não tenham sido apreciadas no processo anterior. Se houver perspectiva de alterar o julgamento anterior, a ação idêntica é admitida. 
Recebido em: 03/12/2015

Aceito em: 17/12/2015

\section{Como citar}

PEREIRA, Luiz Fernando Casagrande. Ações eleitorais. Atualidades sobre conexão, continência, litispendência e coisa julgada. Ballot. Rio de Janeiro: UERJ. Volume 1 Número 2 Setembro/Dezembro 2015. pp. 251279. Disponível em: [http://www.e-publicacoes.uerj.br/index.php/ballot]

\section{cc) (1) (2) (2)}

A Revista Ballot está licenciada sob uma licença Creative Commons Atribuição - Não Comercial - Compartilha Igual 3.0 Não Adaptada. 